\title{
Research on Life Objective Structures of Managers and Entrepreneurs in Serbia
}

\author{
Zvonko Sajfert1, Milan Nikolić1, Dejan Djordjević1, Predrag Atanasković2
}

1Dept. of Management, University of Novi Sad, Technical Faculty “Mihajlo Pupin”, Zrenjanin, Djure Djakovića nn, 23000 Zrenjanin, Serbia, z.sajfert@eunet.yu, mikaczr@sbb.rs, djole@rocketmail.com,

2Dept. of Traffic, University of Novi Sad, Faculty of Technical Sciences, Trg Dositeja Obradovića 6, 21000 Novi Sad, Serbia, pedjaatanaskovic@yahoo.com

\begin{abstract}
The purpose of the paper herein is to investigate the different life objective structures of managers and specialists in public enterprises. Owners of private enterprises - entrepreneurs were analyzed as control group. Considering the data obtained by using the random sampling method, one may come to conclusions concerning the characteristics of the observed population. The research revealed that successful private owners-entrepreneurs, being the capital holders, have different structure of life objectives comparing to both managers and specialists in public organizations. The basic idea is that this can be considered as inseparable part of economic growth in any organization which also reflects on the management as well. Since the entrepreneurs invested the private capital to realize their ideas, it is logical that they want to increase their capital. On the other hand, managers and specialists in public enterprises do not have such a great sense for capital increment. They rather share the capital preferring to be sociable (clubs sponsors, great humanitarians). The reason of such acting can be found in a fact that Serbia was influenced by socialism which further resulted in poor education of managers and specialists to change their way of thinking. Managers as well as specialists should become knowledge workers who shall exchange the knowledge.
\end{abstract}

Key words: life objectives, entrepreneur, manager, specialist, successful business.

\section{Introduction}

The purpose of the research herein is to define the correlation between life objectives of managers, as individuals, and applied management system defined by Renzis Likert (Likert, 1967). Life objectives were defined on the basis of reference (Likert, 1967). Moreover, in defining the life objectives analyzed in the paper herein, the following references were also used: (Braham, 1989; Hariss, 1997; Lunday and Colwing 1996; Meggison, Franklin and Byird, 1995; Donnelly Jr., Gibson and Ivancevich, 1990). The attempt was made in order to link the elements set by Professor Likert. The modification of the objective caused the certain insecurity and change in the way of thinking (Ulrich, and Yeuang, 1989). People look at organization objectives from their own perspective.

According to authors (Weihrich and Koontz, 1993), the aim of all managers is to create a surplus (in business language that means profit). Clear and verified objectives facilitate measurement of the said surplus and enable managers to take successful and efficient actions. The authors further cite: the objectives express final results, so the overall objectives should be supported by lowerrank objectives. Sometimes, the both organization and managers have multiple, reciprocally compatible objectives that could not cause conflict in organization, within the team and even between individuals. Managers on different organizational levels are interested in different objectives.

In his article published in Harvard Business Review, 1957 Mr. Douglas McGregor, a scientist who gave a considerable contribution to Behavioural Science, has criticized conventional appraisal plan applied to subordinates based on their personal characteristics (McGregor, 1957). According to the plan concerned, managers were asked to pass their judgment based on the personal worth of the subordinates. McGregor suggested new approach applied to appraisal of subordinates based on Drucker's concept of Management- by- Objectives (MBO).

Long time ago, research consultants and practitians have understood the importance of individuals to establish their own, individual objectives. Early researches performed in the University of Maryland showed that working efficiency is greater when people have established more specific objectives than when they are simply told to give their best (Edwin and, Bryan, 1967). As a motivation technique, setting of objectives is not limited only to economy; it is, also, useful in public organizations. According to (Weihrich, 1976), the general indefiniteness of objectives in most public organizations is a challenge for managers. However, there are evidences showing that the challenge can be met. The issue here is not about the 
people who simply carry out their assignments, follow the instructions and wait for guidelines and decisions to be made; they are individuals with clearly defined purposes. Employees should participate in setting of their life objectives. If all employees in one organization had the same way of thinking and could be concentrated on the similar objectives, there should be no limits for possible future achievements (Ulrich nad Yeuang, 1989).

When applying for a job, assembly plant within the Honda Factory in Marysville, Ohio asks from the candidate to write an essay explaining why the work for Honda Factory is in compliance with their life objectives. The explanation initiates the set of values candidate posses before he was hired (Ulrich and Yeuang, 1989). Life and career planning programs sponsored by the company become more popular. Programs concerned are realized in classrooms or through symposiums. The participants are asked to be focused on their past, present and future and to work on their life as well as business plans (Butteress and Albrecht, 1979).

Plans are made after performing self-criticism and self-study (Rothenback, 1982). The objective is to make people to observe their life as well as business plans on systematic and complete way. Some of the steps in life and career planning program are as follows: (Donnelly, Jr., Gibson and Ivancevich, 1990)

1. To assess the past life and career, taking notes of the most important events.

2. To formulate objectives related to life style and career course and to predict the future.

3. To develop an action plan for goal achievement and to project a time in which the goal shall be achieved.

According to authors (Donnelly, Jr., Gibson and Ivancevich, 1990), planning of life and career should be done simultaneously, since the career planning is just the one aspect of life planning. Effects life and career planning have on attitudes and behaviour of individual are not yet scientifically proved. The greatest support of this type of program is that the participants are dedicated to their career planning. Enthusiasts who pass the said program claim that they better understand themselves, their career and life style. Moreover, they are less concerned about the future. Since the Serbian economy is in transition, we have started from the assumption that both managers and entrepreneurs have different structure of their life objectives. It is proved that managers and specialists are rather similar comparing to entrepreneurs who differ (Sajfert, Djordjevic and Atanaskovic, 2007).

Since the organization is a public structure with the certain goal, the research herein has to define structure of managers' life objectives. In order to understand and explain the objective as a basic component of the research performed, it is useful to make complete picture of the objective itself and to explain its concept.

Usually, the simplest and the most rational explanation of objective is the one referring to term target, which is the synonym for objective (Peters, 1987). The word target passed from the Latin denotes the goal or objective toward which effort is directed, the limit that need to be reached and overcame (Ichio and Nonaka, 2007). Considering the Greek origin, the word concerned usually appears as linking preposition in numerous compound words denoting change of state, place, order, nature, etc. as well as participation, common action etc. (Von Krogh, Ichio and Nonaka, 2000). According to the mentioned pattern, a numerous expressions denoting processes that require certain changes, have been derivated.

\section{Problem - subject of the research}

The subject of the research is management in enterprise and what to do to increase its efficiency. In order to identify the subject of the research one would start from the importance and role of both managers and entrepreneurs. The goal of the said problem is to identify the influence of certain psychological factors that are considered to be personal characteristics of both managers and entrepreneurs. The said can be realized by using the life objectives test in which different structure of life objectives is identified. Considering both theoretical and practical aspects, the research of the said problem is important, having in mind that psychological factors-life objectives have not been adequately treated in previous researches neither in Serbia nor in world. The past world literature has not defined the relation between life objectives of managers to the management. The research covered three groups. The first group involved 200 managers in public enterprises, randomly chosen. The second group included 200 specialists, also randomly chosen. The third, control group, included the group of 40 private owners - entrepreneurs.

The goal of the research is to complete the scientific knowledge with achievements in theoretical thought so as to find out how structure of managers' life objectives affects the management. The research will prove the relation between structure of managers' life objectives and management structure in enterprise. According to the literature and researches conducted worldwide, no correlation between structure of life objectives of managers and entrepreneurs has been identified. Therefore, the goal of the research is to fill the gap referring to different structure of life objectives of managers and entrepreneurs.

Tasks and research methods. Life objectives of managers and entrepreneurs are the basic principle used to define the tasks within the research performed. Considering the type of the research applied, it can be concluded that the following research methods appeared to be the most appropriate: analysis and analogy, classification and statistics. On the basis of scientific processing of the collected data, it is possible to create a scientific attitude as well as to give an opinion and to offer a thesis referred to the existing state of the system. The research was carried out through the standard phases: research preparation, outline of research methodologies, designing and preparation of instruments, research performing, data processing and announcement of results.

The explanations above are sufficient to identify the objective as a synonym for change that need to be realized, i.e. the goal intended to be attained. All the mentio- 
ned show that both sense and source of the objective lay in man personality i.e. in his ability to define, in thoughtful manner, limits he wants to reach. On the basis of such thoughtful structures, people further make structures by which they reach desirable limits, i.e. certain objective.

Generally, within the structure of life objectives, the priority is usually given to prior satisfaction of physiological needs and to those objectives intended to keep the body in functional state. From the aspects of importance, the following group represents needs for security and freedom in behaviour. People are social beings and therefore need for associating belongs to those life objectives without which social order can not be even imagined. Besides, every man would like to express himself as person, i.e. has certain reputation and importance in society. However, people also want to satisfy the desires, which in certain conditions, are not directly related to survival and existence. Needs in this group are usually considered as luxury. However, together with development of society, luxury gradually becomes a need. This is one of the more characteristic managers' life objectives.

Beside the structure of managers' life objectives mentioned above, it is possible to make other classifications of life objectives, since people direct their desires and aspirations to endlessness which further results in creation of new structure of managers' life objectives. The current managers' life objectives are as follows: wealth, independence, leadership, expertise, creativity, prestige, solidarity, love, safety, sense of duty, pleasure... Therefore, managers' life objectives can be grouped according to the following: possibility of realization, how difficult realization can be, course of realization, who are the carriers of the realization, etc.

Managers' life objectives include numerous elements related to management. The paper herein studies managers' life objectives.

\section{Differences between managers in public and private enterprises}

What is the state of the management in Serbia today? Is there a difference between managers in private and public enterprises? Regarding those questions, there are many speculations and answers without proofs, but only few empiric researches that could give a correct answer. One of such researches is presented in this paper. The paper is mainly based on determination of correlation between life objectives of managers in public enterprises and specialists in private enterprises. The owners of private enterprises were analyzed as a control group. Based on information obtained from randomly chosen samples, conclusions on characteristics of observed population were made. The research shall prove that successful private owners as the capital holders have life objective structure different from the life objective structure of managers in public enterprises and specialists. Life objectives of managers represent a basic principle for formulating the hypothesis in this research. Former researches in Serbia did not determine correlations between the life objective structure of managers as individuals and applied management system established by the professor Renzis Likert, Ph.D. (Likert, 1967). However, this paper takes the viewpoint that such approach for determination of above-mentioned correlations is proper both from the scientific and practical viewpoint.

Persons occupying managerial positions in enterprises have different life objective structures as a consequence of individual psychology, education and cultural environment where they work and develop themselves. Particular life objectives of managers can be grouped around the following factors (motives): 1 leadership, 2 expertise, 3 creativity, 4 prestige, 5 solidarity, 6 wealth, 7 independence, 8 love, 9 security, 10 sense of duty and 11 pleasure. Definition and structure of managers' life objectives can be established in the other way, too. This paper analyzes managers' life objectives related to management. The structure of management objectives is an unavoidable area of management organization in current circumstances of scientific and technical progress and important condition for more successful business operations.

The best and most successful enterprises placed emphasis on people and management of their potentials, preferences and learning. Traditional research on adult learning has two main sources: (Coleman, 1997)

- Research on adult learning and

- Research on experiential learning.

The knowledge identifies conditions under which the persons learn the best characteristics of people who manage the setting of those conditions. The essence is that knowledge management is not significant by itself and for itself, but it should support the mission and business objectives. The list of rules stated here and prepared by the professional service company (Snoveden, 1999) has resulted from the experience in applying the knowledge management in many public and private organizations:

- The information technologies and information management are necessary, but not sufficient.

- The knowledge management focuses its attention to the value of intellectual capital and it concerns people.

- The ideas create ideas: the rational idea provides possibility for development of new and better ideas.

- Knowledge exchange and professional tests are the key to flexibility, quick reacting and success of one organization.

Managers should have the following characteristics: verbal and written communication skills, creativity, innovation, imagination, high motivation, leadership. Moreover, to manage enterprise successfully, the managers shall have self-confidence, capability to solve problems quickly, planning knowledge, business skills, knowledge of interpersonal relation problems and awareness of personal ideas and faults. Life objectives are included in so-called eternal psychological and philosophical questions that each epoch, class, generation and to some extent each individual resolves in a new manner. 
Actuality of the life objective problems is conditioned by the series of causes. Life objective problems are not the new ones, both in Serbia and worldwide. Obviously, the life objectives cannot be considered as a specific, individual problem, since they result from the essence of philosophical concept of human being and a world as a whole. It was taken for granted long ago that the answer to a question about life objectives results from the entire psychology, philosophical system, metaphysics, and sociology being its basis. The wisdom and knowledge in their original meaning are necessary as the knowledge of life and knowledge for life. The life objectives in psychology are both initial and final problems. According to (Wiig, 2004), the best workers learn and apply their knowledge in cooperation with others and at same time recognize the quantity of information and knowledge required for resolving the complex situation and problems.

There are four main processes in the organization: creating the ideas, resolving the problems, decision making and taking the efficient action (Kolb, 1984). These processes shall be implemented by each individual knowledge workers or team or groups of human resources. Each process is a chance for knowledge workers to learn and extend their knowledge and experience.

\section{Research results}

Differentiation between managers in private and public enterprises was made using life objective test. The research was performed both theoretically and empirically. Empiric research was performed using life objectives test based on anonymous questionnaire. 200 managers from public enterprises were chosen for this empiric research and control group was formed of 40 successful private owners - entrepreneurs. The research was performed in Serbia, in the period June 2005 - December 2006.

The sample of public enterprise managers includes all management levels: from the managing director and members of the board of managers through managers of profitable enterprise sectors and project managers to the functional managers such as: financial, marketing, production, human resources, IT, research and development managers. It may be concluded that research was reduced to the top and middle enterprise management levels which are the most important for making difference between private and public enterprise management. The sample included managers of enterprises in all industry branches, different in size and legal status.

Data obtained from life objective test were processed using multivariation analysis method (variance analysis, cluster analysis) and x2 (Hi - square) test (Sajfert, Djordjevic and Atanaskovic, 2007). Table of frequencies determined numerical and percentage correlation between two groups of managers and one group of private owners - entrepreneurs.

Results of statistical data processing were given in a form of structure showing the arrangement of statistical sets by value of characteristics. Series of structures cannot be treated as frequencies since the characteristic based on which they are formed is not the variable value. Therefore they could not be mathematically processed as frequency arrangements. Data collected in this research were processed in the following sequence:

- Persons questioned were divided into three groups: managers, specialists and entrepreneurs. The primary processing includes sorting of answers by formulation type.

- Answers given in the research were counted for each of above-mentioned group, relative frequency of all attributive characteristics was calculated on the basis of total number of options for all alternatives and obtained results were sorted in tables containing the rank.

- Data from those tables were graphically presented in bar charts in the following manner: relevant frequencies were plotted on the ordinate and attributive characteristics on the abscissa.

- On all figures the first rectangle indicates the answers of entrepreneurs, second rectangle indicates the answers of managers and the third one indicates the answers of specialists.

Research results are shown in tables 1-11 and figures 1-11. Research results were given for all 11 analyzed life objectives: 1 leadership, 2 expertise, 3 creativity, 4 prestige, 5 solidarity, 6 wealth, 7 independence, 8 love, 9 security, 10 sense of duty and 11 pleasure.

Table 1. Statistical data for life objective: 1. leadership

\begin{tabular}{|c|c|c|c|c|c|c|c|c|c|c|c|c|c|c|}
\hline \multicolumn{5}{|c|}{ FREQUENCY TABLE (LEADERSHIP) } & \multicolumn{5}{|c|}{$\begin{array}{l}\text { COLUMN TABLE STRUCTURE } \\
\text { (LEADERSHIP) }\end{array}$} & \multicolumn{5}{|c|}{ MINIMUM ESTIMATED EXPECTED VALUE IS $\quad 0.09$} \\
\hline & \multicolumn{3}{|c|}{ Group } & \multirow[b]{2}{*}{ Total } & & \multicolumn{3}{|c|}{ Group } & \multirow[b]{2}{*}{ Total } & STATISTIC & \begin{tabular}{|l|} 
VALUE \\
\end{tabular} & D.F. & PROB. & \\
\hline & Private & $\begin{array}{c}\text { Mana- } \\
\text { ger }\end{array}$ & Spec. & & & Private & $\begin{array}{c}\text { Mana- } \\
\text { ger }\end{array}$ & Spec. & & PEARSON CHISQUARE & 263.497 & 20 & 0.0 & \\
\hline 1 & 3 & 3 & 0 & 6 & 1 & 7.5 & 1.5 & 0.0 & 1.4 & PHI & 0.774 & & & \\
\hline 2 & 2 & 4 & 1 & 7 & 2 & 5.0 & 2.0 & 0.5 & 1.6 & CONTIGENCY COEF. C & 0.612 & & & \\
\hline 3 & 11 & 2 & 0 & 13 & 3 & 27.5 & 1.0 & 0.0 & 3.0 & CRAMER'S V & 0.547 & & & \\
\hline 4 & 1 & 0 & 0 & 1 & 4 & 2.5 & 0.0 & 0.0 & 0.2 & & & & & \\
\hline 5 & 3 & 3 & 2 & 8 & 5 & 7.5 & 1.5 & 1.0 & 1.8 & STATISTIC & VALUE & ASE1 & $\begin{array}{c}\text { T- } \\
\text { VALUE }\end{array}$ & $\begin{array}{l}\mathrm{DE} \\
\mathrm{P} .\end{array}$ \\
\hline 6 & 1 & 3 & 0 & 4 & 6 & 2.5 & 1.5 & 0.0 & 0.9 & GAMMA & 0.347 & 0.061 & 5.201 & \\
\hline 7 & 10 & 2 & 0 & 12 & 7 & 25.0 & 1.0 & 0.0 & 2.7 & KENDALL TAU-B & 0.238 & 0.044 & 5.201 & \\
\hline 8 & 7 & 7 & 5 & 19 & 8 & 17.5 & 3.5 & 2.5 & 4.3 & STUART TAU-C & 0.236 & 0.045 & 5.201 & \\
\hline 9 & 0 & 45 & 59 & 104 & 9 & 0.0 & 22.5 & 29.5 & 23.6 & SOMERS D & 0.209 & 0.039 & 5.201 & 1 \\
\hline 10 & 0 & 57 & 57 & 114 & 10 & 0.0 & 28.5 & 28.5 & 25.9 & \begin{tabular}{|l|} 
SOMERS D \\
\end{tabular} & 0.272 & 0.050 & 5.201 & 3 \\
\hline 11 & 2 & 74 & 76 & 152 & 11 & 5.0 & 37.0 & 38.0 & 34.5 & CORRELATION COEF. & 0.453 & 0.043 & 6.629 & \\
\hline Total & 40 & 200 & 200 & 440 & Total & 100.0 & 100.0 & 100.0 & 100.0 & $\begin{array}{l}\text { SPEARMAN RANK } \\
\text { CORR. }\end{array}$ & 0.275 & 0.049 & 5.439 & \\
\hline
\end{tabular}


LEADERSHIP AS A LIFE GOAL

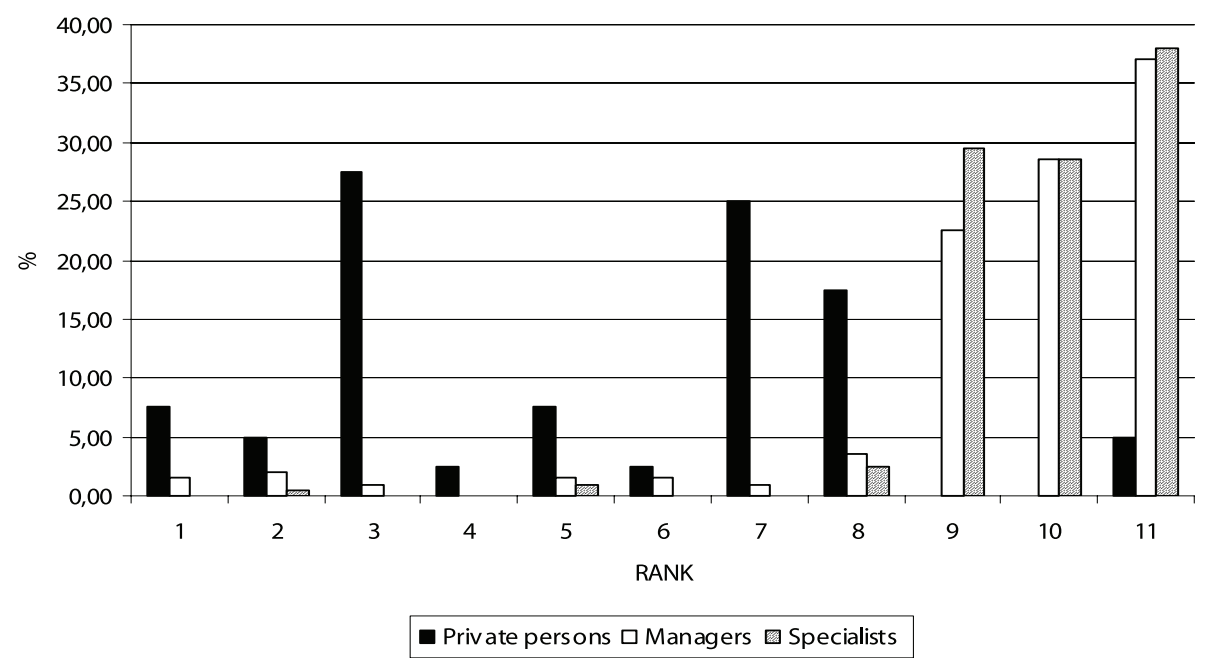

Figure 1. Leadership, as a life objective, is observable in successful private owners, and poorly noticeable in specialists and managers in public enterprises

Table 2. Statistical data for life objective: 2.expertise

\begin{tabular}{|c|c|c|c|c|c|c|c|c|c|c|c|c|c|c|}
\hline \multicolumn{5}{|c|}{ FREQUENCY TABLE (EXPERTISE) } & \multicolumn{5}{|c|}{$\begin{array}{l}\text { COLUMN TABLE STRUCTURE } \\
\text { (EXPERTISE) }\end{array}$} & \multicolumn{5}{|c|}{ MINIMUM ESTIMATED EXPECTED VALUE IS $\quad 0.09$} \\
\hline & \multicolumn{3}{|c|}{ Group } & \multirow[b]{2}{*}{ Total } & & \multicolumn{3}{|c|}{ Group } & \multirow[b]{2}{*}{ Total } & STATISTIC & VALUE & D.F. & PROB. & \\
\hline & Private & $\begin{array}{c}\text { Mana- } \\
\text { ger }\end{array}$ & Spec. & & & Private & $\begin{array}{c}\text { Mana- } \\
\text { ger }\end{array}$ & Spec. & & PEARSON CHISQUARE & 127.398 & 20 & 0.0 & \\
\hline 1 & 1 & 0 & 0 & 1 & 1 & 2.5 & 0.0 & 0.0 & 0.2 & PHI & 0.538 & & & \\
\hline 2 & 0 & 3 & 0 & 3 & 2 & 0.0 & 1.5 & 0.0 & 0.7 & CONTIGENCY COEF. C & 0.474 & & & \\
\hline 3 & 5 & 2 & 0 & 7 & 3 & 12.5 & 1.0 & 0.0 & 1.6 & CRAMER'S V & 0.380 & & & \\
\hline 4 & 4 & 24 & 25 & 53 & 4 & 10.0 & 12.0 & 12.5 & 12.0 & & & & & \\
\hline 5 & 0 & 39 & 36 & 75 & 5 & 0.0 & 19.5 & 18.0 & 17.0 & STATISTIC & VALUE & ASE1 & $\begin{array}{c}\text { T- } \\
\text { VALUE } \\
\end{array}$ & $\begin{array}{l}\text { DE } \\
\text { P. }\end{array}$ \\
\hline 6 & 6 & 34 & 29 & 69 & 6 & 15.0 & 17.0 & 14.5 & 15.7 & GAMMA & 0.006 & 0.064 & 0.101 & \\
\hline 7 & 1 & 38 & 26 & 65 & 7 & 2.5 & 19.0 & 13.0 & 14.8 & KENDALL TAU-B & 0.005 & 0.046 & 0.101 & \\
\hline 8 & 2 & 40 & 53 & 95 & 8 & 5.0 & 20.0 & 26.5 & 21.6 & $\begin{array}{l}\text { STUART TAU-C } \\
\end{array}$ & 0.005 & 0.048 & 0.101 & \\
\hline 9 & 4 & 11 & 17 & 32 & 9 & 10.0 & 5.5 & 8.5 & 7.3 & SOMERS D & 0.004 & 0.038 & 0.101 & 1 \\
\hline 10 & 11 & 4 & 10 & 25 & 10 & 27.5 & 2.0 & 5.0 & 5.7 & SOMERS D & 0.006 & 0.055 & 0.101 & 4 \\
\hline 11 & 6 & 5 & 4 & 15 & 11 & 15.0 & 2.5 & 2.0 & 3.4 & CORRELATION COEF. & -0.032 & 0.059 & -0.537 & \\
\hline Total & 40 & 200 & 200 & 440 & Total & 100.0 & 100.0 & 100.0 & 100.0 & $\begin{array}{l}\text { SPEARMAN RANK } \\
\text { CORR. }\end{array}$ & 0.002 & 0.053 & 0.035 & \\
\hline
\end{tabular}

EXPERTISE AS A LIFE GOAL

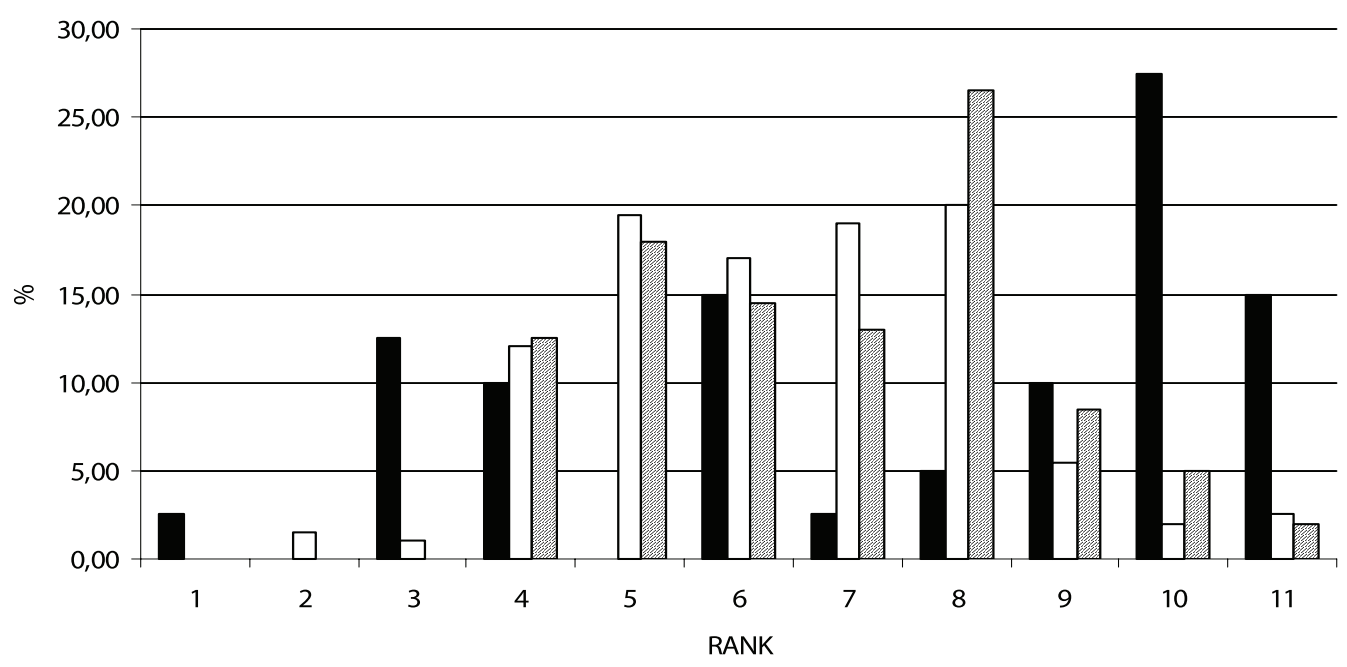

- Private persons $\square$ Managers 0 Specialists

Figure 2. Expertise is not interesting for any of the groups examined 
Table 3. Statistical data for life objective: 3. creativity

\begin{tabular}{|c|c|c|c|c|c|c|c|c|c|c|c|c|c|c|}
\hline \multicolumn{5}{|c|}{ FREQUENCY TABLE (CREATIVITY) } & \multicolumn{5}{|c|}{$\begin{array}{l}\text { COLUMN TABLE STRUCTURE } \\
\text { (CREATIVITY) }\end{array}$} & \multicolumn{5}{|c|}{ MINIMUM ESTIMATED EXPECTED VALUE IS $\quad 0.18$} \\
\hline & \multicolumn{3}{|c|}{ Group } & \multirow[b]{2}{*}{ Total } & & \multicolumn{3}{|c|}{ Group } & \multirow[b]{2}{*}{ Total } & STATISTIC & VALUE & D.F. & PROB. & \\
\hline & Private & $\begin{array}{c}\text { Mana- } \\
\text { ger }\end{array}$ & Spec. & & & Private & $\begin{array}{c}\text { Mana- } \\
\text { ger }\end{array}$ & Spec. & & PEARSON CHISQUARE & 77.117 & 20 & 0.0 & \\
\hline 1 & 3 & 4 & 0 & 7 & 1 & 7.5 & 2.0 & 0.0 & 1.6 & PHI & 0.419 & & & \\
\hline 2 & 6 & 4 & 2 & 12 & 2 & 15.0 & 2.0 & 1.0 & 2.7 & CONTIGENCY COEF. C & 0.386 & & & \\
\hline 3 & 2 & 12 & 3 & 17 & 3 & 5.0 & 6.0 & 1.5 & 3.9 & CRAMER'S V & 0.296 & & & \\
\hline 4 & 3 & 33 & 21 & 57 & 4 & 7.5 & 16.5 & 10.5 & 13.0 & & & & & \\
\hline 5 & 18 & 43 & 54 & 115 & 5 & 45.0 & 21.5 & 27.0 & 26.1 & STATISTIC & VALUE & ASE1 & $\begin{array}{c}\text { T- } \\
\text { VALUE }\end{array}$ & $\begin{array}{l}\text { DE } \\
\text { P. }\end{array}$ \\
\hline 6 & 3 & 34 & 36 & 73 & 6 & 7.5 & 17.0 & 18.0 & 16.6 & GAMMA & 0.260 & 0.055 & 4.588 & \\
\hline 7 & 1 & 40 & 36 & 77 & 7 & 2.5 & 20.0 & 18.0 & 17.5 & KENDALL TAU-B & 0.182 & 0.039 & 4.588 & \\
\hline 8 & 2 & 16 & 35 & 53 & 8 & 5.0 & 8.0 & 17.5 & 12.0 & STUART TAU-C & 0.190 & 0.041 & 4.588 & \\
\hline 9 & 1 & 9 & 7 & 17 & 9 & 2.5 & 4.5 & 3.5 & 3.9 & SOMERS D & 0.151 & 0.033 & 4.588 & 1 \\
\hline 10 & 0 & 4 & 6 & 10 & 10 & 0.0 & 2.0 & 3.0 & 2.3 & SOMERS D & 0.219 & 0.047 & 4.588 & 5 \\
\hline 11 & 1 & 1 & 0 & 2 & 11 & 2.5 & 0.5 & 0.0 & 0.5 & CORRELATION COEF. & 0.235 & 0.048 & 4.527 & \\
\hline Total & 40 & 200 & 200 & 440 & Total & 100.0 & 100.0 & 100.0 & 100.0 & $\begin{array}{l}\text { SPEARMAN RANK } \\
\text { CORR. }\end{array}$ & 0.214 & 0.046 & 4.630 & \\
\hline
\end{tabular}

CREATIVITY AS A LIFE GOAL

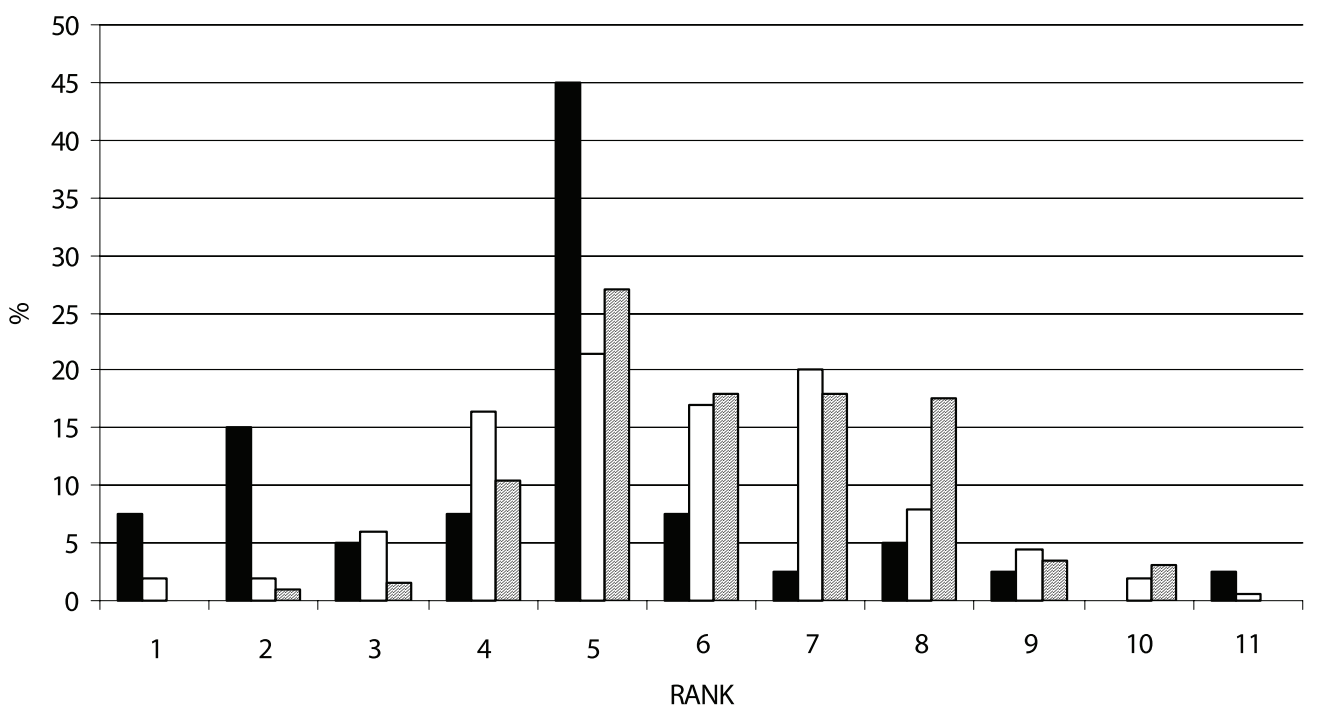

Private persons $\square$ Managers $\quad$ Specialists

Figure 3. Creativity is not considered to be an important parameter in all three groups

Table 4. Statistical data for life objective: 4. prestige

\begin{tabular}{|c|c|c|c|c|c|c|c|c|c|c|c|c|c|c|}
\hline \multicolumn{5}{|c|}{ FREQUENCY TABLE (PRESTIGE) } & \multicolumn{5}{|c|}{$\begin{array}{l}\text { COLUMN TABLE STRUCTURE } \\
\text { (PRESTIGE) }\end{array}$} & \multicolumn{5}{|c|}{ MINIMUM ESTIMATED EXPECTED VALUE IS $\quad 0.73$} \\
\hline & \multicolumn{3}{|c|}{ Group } & \multirow[b]{2}{*}{ Total } & & \multicolumn{3}{|c|}{ Group } & \multirow[b]{2}{*}{ Total } & STATISTIC & VALUE & D.F. & PROB. & \\
\hline & Private & $\begin{array}{l}\text { Mana- } \\
\text { ger }\end{array}$ & Spec. & & & Private & $\begin{array}{l}\text { Mana- } \\
\text { ger }\end{array}$ & Spec. & & PEARSON CHISQUARE & 142.651 & 20 & 0.0 & \\
\hline 1 & 4 & 4 & 0 & 8 & 1 & 10.0 & 2.0 & 0.0 & 1.8 & PHI & 0.569 & & & \\
\hline 2 & 12 & 6 & 2 & 20 & 2 & 30.0 & 3.0 & 1.0 & 4.5 & CONTIGENCY COEF. C & 0.495 & & & \\
\hline 3 & 3 & 7 & 4 & 14 & 3 & 7.5 & 3.5 & 2.0 & 3.2 & CRAMER'S V & 0.403 & & & \\
\hline 4 & 4 & 3 & 1 & 8 & 4 & 10.0 & 1.5 & 0.5 & 1.8 & & & & & \\
\hline 5 & 3 & 10 & 9 & 22 & 5 & 7.5 & 5.0 & 4.5 & 5.0 & STATISTIC & VALUE & ASE1 & $\begin{array}{c}\text { T- } \\
\text { VALUE }\end{array}$ & $\begin{array}{l}\mathrm{DE} \\
\mathrm{P} .\end{array}$ \\
\hline 6 & 3 & 4 & 2 & 9 & 6 & 7.5 & 2.0 & 1.0 & 2.0 & GAMMA & 0.386 & 0.054 & 6.479 & \\
\hline 7 & 2 & 5 & 4 & 11 & 7 & 5.0 & 2.5 & 2.0 & 2.5 & KENDALL TAU-B & 0.271 & 0.040 & 6.479 & \\
\hline 8 & 5 & 9 & 9 & 23 & 8 & 12.5 & 4.5 & 4.5 & 5.2 & STUART TAU-C & 0.277 & 0.043 & 6.479 & \\
\hline 9 & 3 & 42 & 45 & 90 & 9 & 7.5 & 21.0 & 22.5 & 20.5 & SOMERS D & 0.229 & 0.035 & 6.479 & 1 \\
\hline 10 & 1 & 57 & 55 & 113 & 10 & 2.5 & 28.5 & 27.5 & 25.7 & SOMERS D & 0.319 & 0.046 & 6.479 & 6 \\
\hline 11 & 0 & 53 & 69 & 122 & 11 & 0.0 & 26.5 & 34.5 & 27.7 & CORRELATION COEF. & 0.418 & 0.045 & 6.829 & \\
\hline Total & 40 & 200 & 200 & 440 & Total & 100.0 & 100.0 & 100.0 & 100.0 & $\begin{array}{l}\text { SPEARMAN RANK } \\
\text { CORR. }\end{array}$ & 0.314 & 0.046 & 6.682 & \\
\hline
\end{tabular}




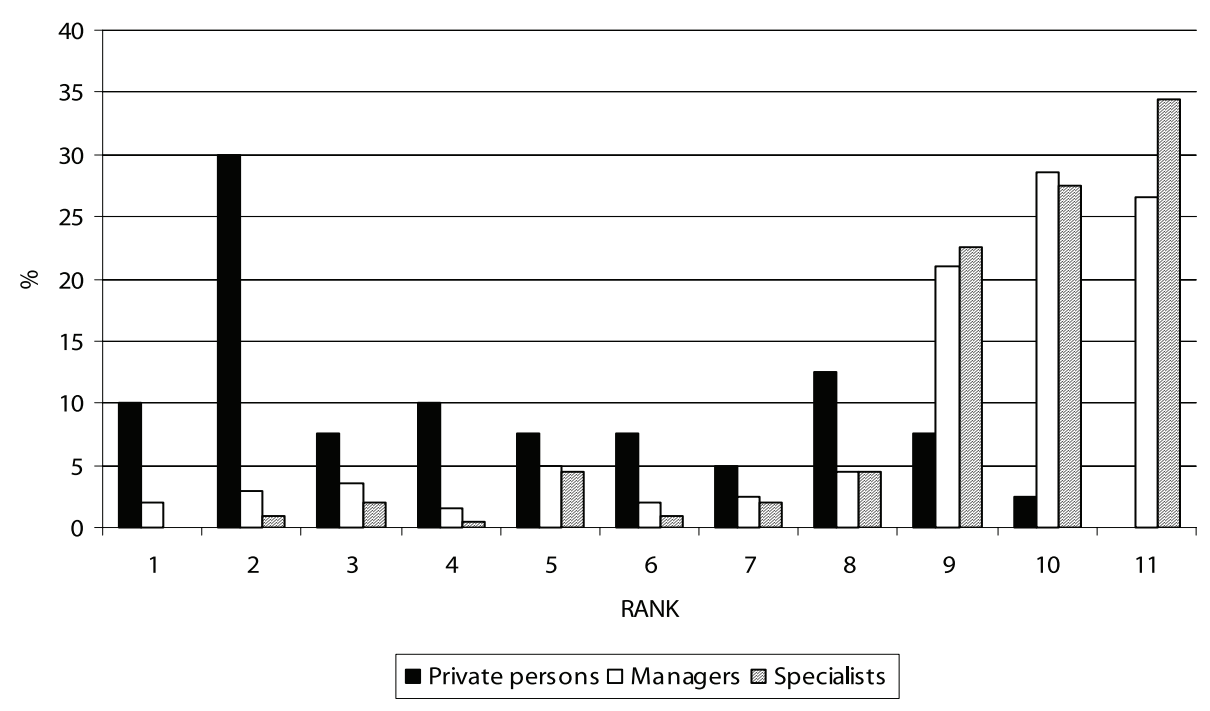

Figure 4. Prestige, as a life objective, is noticeable in successful private owners, while in specialists and managers in public enterprises the parameter concerned is not relevant

Table 5. Statistical data for life objective: 5. solidarity

\begin{tabular}{|c|c|c|c|c|c|c|c|c|c|c|c|c|c|c|}
\hline \multicolumn{5}{|c|}{ FREQUENCY TABLE (SOLIDARITY) } & \multicolumn{5}{|c|}{$\begin{array}{l}\text { COLUMN TABLE STRUCTURE } \\
\text { (SOLIDARITY) }\end{array}$} & \multicolumn{5}{|c|}{ MINIMUM ESTIMATED EXPECTED VALUE IS $\quad 0.27$} \\
\hline & \multicolumn{3}{|c|}{ Group } & \multirow[b]{2}{*}{ Total } & & \multicolumn{3}{|c|}{ Group } & \multirow[b]{2}{*}{ Total } & STATISTIC & VALUE & D.F. & PROB. & \\
\hline & Private & $\begin{array}{c}\text { Mana- } \\
\text { ger }\end{array}$ & Spec. & & & Private & $\begin{array}{c}\text { Mana- } \\
\text { ger }\end{array}$ & Spec. & & PEARSON CHISQUARE & 252.633 & 20 & 0.0 & \\
\hline 1 & 0 & 90 & 90 & 180 & 1 & 0.0 & 45.0 & 45.0 & 40.9 & PHI & 0.758 & & & \\
\hline 2 & 3 & 59 & 46 & 108 & 2 & 7.5 & 29.5 & 23.0 & 24.5 & CONTIGENCY COEF. C & 0.604 & & & \\
\hline 3 & 0 & 35 & 47 & 82 & 3 & 0.0 & 17.5 & 23.5 & 18.6 & CRAMER'S V & 0.536 & & & \\
\hline 4 & 3 & 2 & 3 & 8 & 4 & 7.5 & 1.0 & 1.5 & 1.8 & & & & & \\
\hline 5 & 2 & 2 & 4 & 8 & 5 & 5.0 & 1.0 & 2.0 & 1.8 & STATISTIC & VALUE & ASE1 & $\begin{array}{c}\text { T- } \\
\text { VALUE }\end{array}$ & $\begin{array}{l}\mathrm{DE} \\
\mathrm{P} .\end{array}$ \\
\hline 6 & 0 & 2 & 1 & 3 & 6 & 0.0 & 1.0 & 0.5 & 0.7 & GAMMA & -0.296 & 0.063 & -4.318 & \\
\hline 7 & 16 & 1 & 2 & 19 & 7 & 40.0 & 0.5 & 1.0 & 4.3 & KENDALL TAU-B & -0.202 & 0.045 & -4.318 & \\
\hline 8 & 1 & 2 & 2 & 5 & 8 & 2.5 & 1.0 & 1.0 & 1.1 & STUART TAU-C & -0.197 & 0.046 & -4.318 & \\
\hline 9 & 7 & 2 & 4 & 13 & 9 & 17.5 & 1.0 & 2.0 & 3.0 & SOMERS D & -0.179 & 0.041 & -4.318 & 1 \\
\hline 10 & 7 & 3 & 1 & 11 & 10 & 17.5 & 1.5 & 0.5 & 2.5 & SOMERS D & -0.227 & 0.050 & -4.318 & 7 \\
\hline 11 & 1 & 2 & 0 & 3 & 11 & 2.5 & 1.0 & 0.0 & 0.7 & CORRELATION COEF. & -0.416 & 0.050 & -5.962 & \\
\hline Total & 40 & 200 & 200 & 440 & Total & 100.0 & 100.0 & 100.0 & 100.0 & $\begin{array}{l}\text { SPEARMAN RANK } \\
\text { CORR. }\end{array}$ & -0.232 & 0.051 & -4.493 & \\
\hline
\end{tabular}

SOLIDARITY AS A LFE GOAL

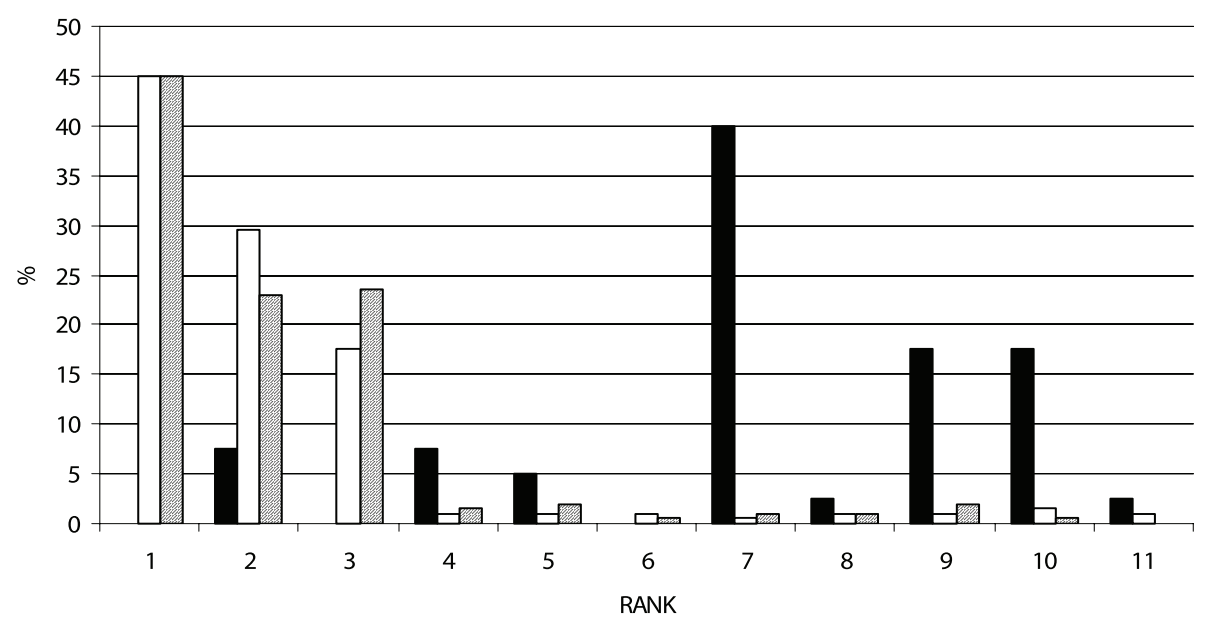

- Private persons $\square$ Managers $\square$ Specialists

Figure 5. Solidarity, as a life objective, is very interesting for specialists and managers, and not relevant for successful entrepreneurs 
Table 6. Statistical data for life objective: 6. wealth

\begin{tabular}{|c|c|c|c|c|c|c|c|c|c|c|c|c|c|c|}
\hline \multicolumn{5}{|c|}{ FREQUENCY TABLE (WEALTH) } & \multicolumn{5}{|c|}{ COLUMN TABLE STRUCTURE (WEALTH) } & \multicolumn{5}{|c|}{ MINIMUM ESTIMATED EXPECTED VALUE IS $\quad 0.82$} \\
\hline & \multicolumn{3}{|c|}{ Group } & \multirow[b]{2}{*}{ Total } & & \multicolumn{3}{|c|}{ Group } & \multirow[b]{2}{*}{ Total } & STATISTIC & \begin{tabular}{|l} 
VALUE \\
\end{tabular} & D.F. & PROB. & \\
\hline & Private & $\begin{array}{c}\text { Mana- } \\
\text { ger }\end{array}$ & Spec. & & & Private & $\begin{array}{c}\text { Mana- } \\
\text { ger }\end{array}$ & Spec. & & PEARSON CHISQUARE & 190.265 & 20 & 0.0 & \\
\hline 1 & 17 & 4 & 3 & 24 & 1 & 42.5 & 2.0 & 1.5 & 5.5 & PHI & 0.658 & & & \\
\hline 2 & 9 & 7 & 12 & 28 & 2 & 22.5 & 3.5 & 6.0 & 6.4 & CONTIGENCY COEF. C & 0.549 & & & \\
\hline 3 & 6 & 6 & 17 & 29 & 3 & 15.0 & 3.0 & 8.5 & 6.6 & CRAMER'S V & 0.465 & & & \\
\hline 4 & 3 & 3 & 4 & 10 & 4 & 7.5 & 1.5 & 2.0 & 2.3 & & & & & \\
\hline 5 & 0 & 6 & 7 & 13 & 5 & 0.0 & 3.0 & 3.5 & 3.0 & STATISTIC & VALUE & ASE1 & $\begin{array}{c}\mathrm{T}- \\
\text { VALUE }\end{array}$ & $\begin{array}{c}\text { DE } \\
P .\end{array}$ \\
\hline 6 & 0 & 5 & 4 & 9 & 6 & 0.0 & 2.5 & 2.0 & 2.0 & GAMMA & 0.279 & 0.059 & 4.443 & \\
\hline 7 & 4 & 7 & 2 & 13 & 7 & 10.0 & 3.5 & 1.0 & 3.0 & KENDALL TAU-B & 0.199 & 0.044 & 4.443 & \\
\hline 8 & 0 & 10 & 9 & 19 & 8 & 0.0 & 5.0 & 4.5 & 4.3 & STUART TAU-C & 0.207 & 0.047 & 4.443 & \\
\hline 9 & 1 & 52 & 34 & 87 & 9 & 2.5 & 26.0 & 17.0 & 19.8 & SOMERS D & 0.166 & 0.037 & 4.443 & 1 \\
\hline 10 & 0 & 51 & 57 & 108 & 10 & 0.0 & 25.5 & 28.5 & 24.5 & SOMERS D & 0.239 & 0.051 & 4.443 & 8 \\
\hline 11 & 0 & 49 & 51 & 100 & 11 & 0.0 & 24.5 & 25.5 & 22.7 & CORRELATION COEF. & 0.315 & 0.053 & 5.039 & \\
\hline Total & 40 & 200 & 200 & 440 & Total & 100.0 & 100.0 & 100.0 & 100.0 & $\begin{array}{l}\text { SPEARMAN RANK } \\
\text { CORR. }\end{array}$ & 0.232 & 0.050 & 4.567 & \\
\hline
\end{tabular}

WEALTH AS A LFE GOAL

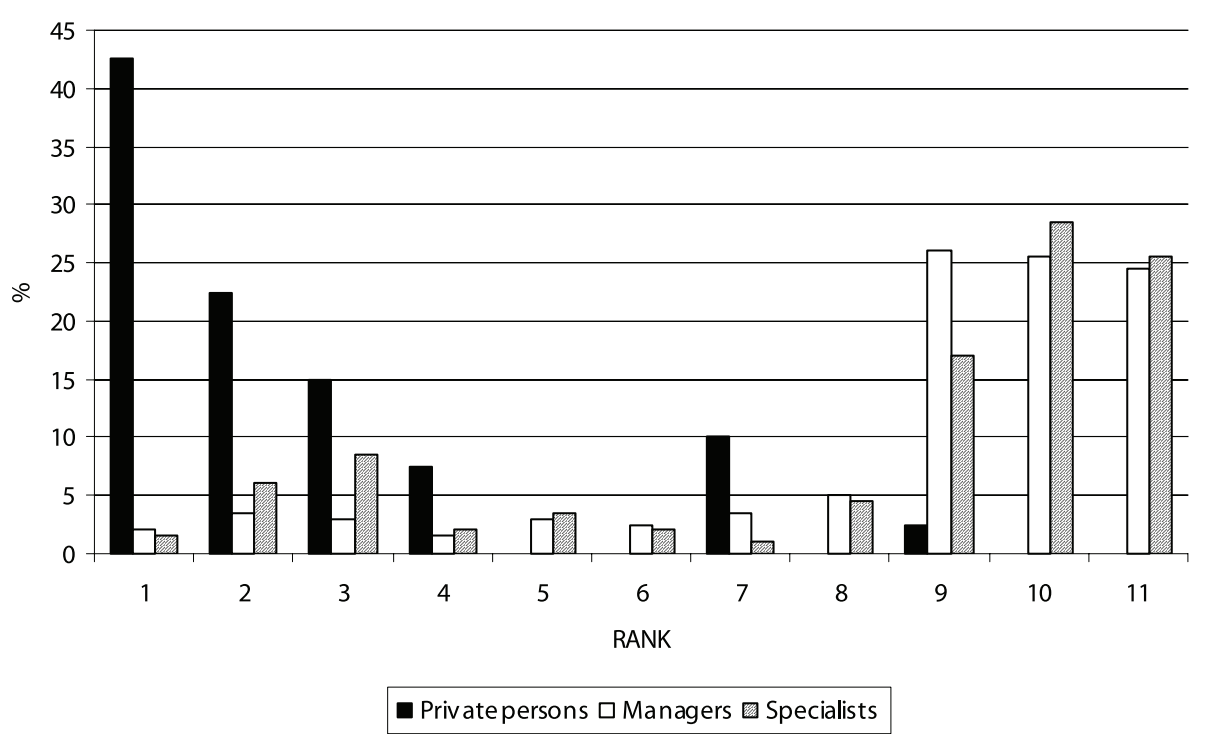

Figure 6. Wealth, as a life objective, is highly-ranked in successful private owners, and very low in specialists and managers in public enterprises

Table 7. Statistical data for life objective: 7. independence

\begin{tabular}{|c|c|c|c|c|c|c|c|c|c|c|c|c|c|c|}
\hline \multicolumn{5}{|c|}{ FREQUENCY TABLE (INDEPENDENCE) } & \multicolumn{5}{|c|}{$\begin{array}{l}\text { COLUMN TABLE STRUCTURE } \\
\text { (INDEPEND.) }\end{array}$} & \multicolumn{5}{|c|}{ MINIMUM ESTIMATED EXPECTED VALUE IS $\quad 0.09$} \\
\hline & \multicolumn{3}{|c|}{ Group } & \multirow[b]{2}{*}{ Total } & & \multicolumn{3}{|c|}{ Group } & \multirow[b]{2}{*}{ Total } & \begin{tabular}{|l|} 
STATISTIC \\
\end{tabular} & \begin{tabular}{|l|} 
VALUE \\
\end{tabular} & D.F. & PROB. & \\
\hline & Private & $\begin{array}{l}\text { Mana- } \\
\text { ger }\end{array}$ & Spec. & & & Private & $\begin{array}{l}\text { Mana- } \\
\text { ger }\end{array}$ & Spec. & & PEARSON CHISQUARE & 104.277 & 20 & 0.0 & \\
\hline 1 & 5 & 65 & 61 & 131 & 1 & 12.5 & 32.5 & 30.5 & 29.8 & PHI & 0.487 & & & \\
\hline 2 & 5 & 64 & 67 & 136 & 2 & 12.5 & 32.0 & 33.5 & 30.9 & CONTIGENCY COEF. C & 0.438 & & & \\
\hline 3 & 3 & 39 & 48 & 90 & 3 & 7.5 & 19.5 & 24.0 & 20.5 & CRAMER'S V & 0.344 & & & \\
\hline 4 & 0 & 2 & 4 & 6 & 4 & 0.0 & 1.0 & 2.0 & 1.4 & & & & & \\
\hline 5 & 5 & 5 & 9 & 19 & 5 & 12.5 & 2.5 & 4.5 & 4.3 & STATISTIC & VALUE & ASE1 & $\begin{array}{c}\text { T- } \\
\text { VALUE }\end{array}$ & $\begin{array}{l}\mathrm{DE} \\
\mathrm{P} .\end{array}$ \\
\hline 6 & 3 & 5 & 3 & 11 & 6 & 7.5 & 2.5 & 1.5 & 2.5 & GAMMA & -0.210 & 0.063 & -3.201 & \\
\hline 7 & 0 & 1 & 0 & 1 & 7 & 0.0 & 0.5 & 0.0 & 0.2 & KENDALL TAU-B & -0.143 & 0.044 & -3.201 & \\
\hline 8 & 6 & 10 & 7 & 23 & 8 & 15.0 & 5.0 & 3.5 & 5.2 & STUART TAU-C & -0.143 & 0.045 & -3.201 & \\
\hline 9 & 5 & 4 & 0 & 9 & 9 & 12.5 & 2.0 & 0.0 & 2.0 & SOMERS D & -0.124 & 0.038 & -3.201 & 1 \\
\hline 10 & 2 & 1 & 1 & 4 & 10 & 5.0 & 0.5 & 0.5 & 0.9 & SOMERS D & -0.165 & 0.050 & -3.201 & 9 \\
\hline 11 & 6 & 4 & 0 & 10 & 11 & 15.0 & 2.0 & 0.0 & 2.3 & CORRELATION COEF. & -0.332 & 0.050 & -5.150 & \\
\hline Total & 40 & 200 & 200 & 440 & Total & 100.0 & 100.0 & 100.0 & 100.0 & $\begin{array}{l}\text { SPEARMAN RANK } \\
\text { CORR. }\end{array}$ & -0.167 & 0.050 & -3.314 & \\
\hline
\end{tabular}


INDEPENDENCE AS A LIFE GOAL

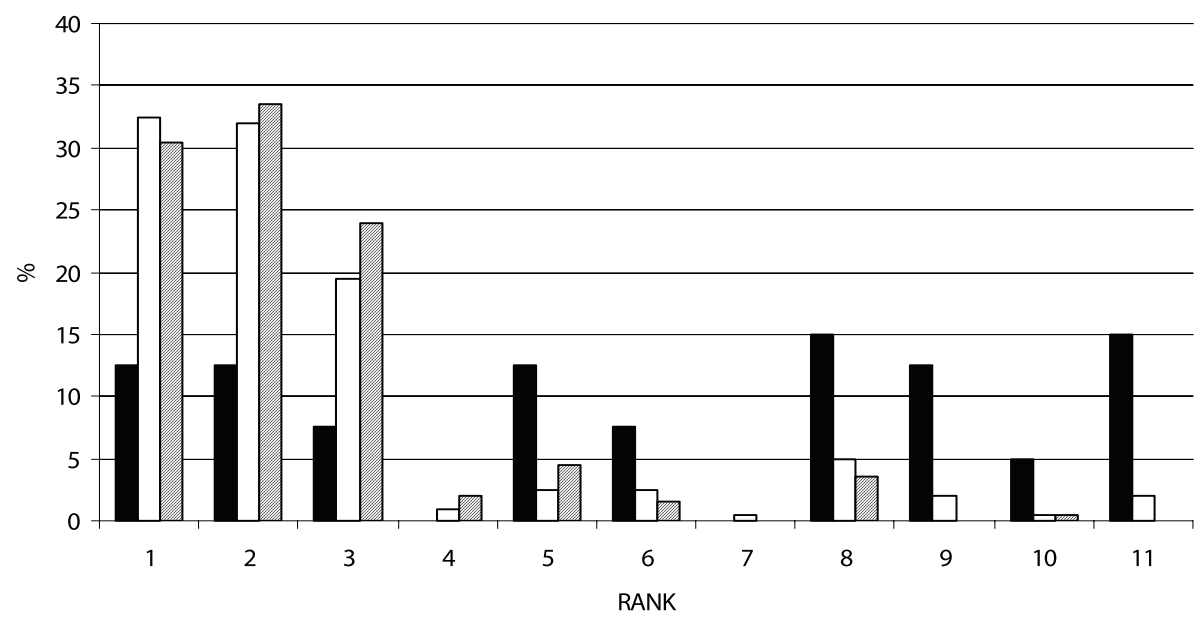

- Private persons $\square$ Managers $\square$ Specialists

Figure 7. Independence, as life objective is more interesting in specialists and managers in public enterprises than in successful private owners

Table 8. Statistical data for life objective: 8. love

\begin{tabular}{|c|c|c|c|c|c|c|c|c|c|c|c|c|c|c|}
\hline & \multicolumn{4}{|c|}{ FREQUENCY TABLE (LOVE) } & \multicolumn{5}{|c|}{ COLUMN TABLE STRUCTURE (LOVE) } & \multicolumn{5}{|c|}{ MINIMUM ESTIMATED EXPECTED VALUE IS $\quad 0.45$} \\
\hline & \multicolumn{3}{|c|}{ Group } & \multirow[b]{2}{*}{ Total } & & \multicolumn{3}{|c|}{ Group } & \multirow[b]{2}{*}{ Total } & STATISTIC & VALUE & D.F. & PROB. & \\
\hline & Private & $\begin{array}{l}\text { Mana- } \\
\text { ger }\end{array}$ & Spec. & & & Private & $\begin{array}{c}\text { Mana- } \\
\text { ger }\end{array}$ & Spec. & & PEARSON CHISQUARE & 113.859 & 20 & 0.0 & \\
\hline 1 & 1 & 2 & 2 & 5 & 1 & 2.5 & 1.0 & 1.0 & 1.1 & PHI & 0.509 & & & \\
\hline 2 & 0 & 4 & 13 & 17 & 2 & 0.0 & 2.0 & 6.5 & 3.9 & CONTIGENCY COEF. C & 0.453 & & & \\
\hline 3 & 4 & 27 & 20 & 51 & 3 & 10.0 & 13.5 & 10.0 & 11.6 & CRAMER'S V & 0.360 & & & \\
\hline 4 & 3 & 42 & 39 & 84 & 4 & 7.5 & 21.0 & 19.5 & 19.1 & & & & & \\
\hline 5 & 5 & 45 & 32 & 82 & 5 & 12.5 & 22.5 & 16.0 & 18.6 & STATISTIC & VALUE & ASE1 & $\begin{array}{c}\text { T- } \\
\text { VALUE }\end{array}$ & $\begin{array}{c}\mathrm{DE} \\
\mathrm{P} .\end{array}$ \\
\hline 6 & 7 & 22 & 48 & 77 & 6 & 17.5 & 11.0 & 24.0 & 17.5 & GAMMA & -0.141 & 0.059 & -2.353 & \\
\hline 7 & 0 & 22 & 22 & 44 & 7 & 0.0 & 11.0 & 11.0 & 10.0 & KENDALL TAU-B & -0.101 & 0.043 & -2.353 & \\
\hline 8 & 2 & 24 & 19 & 45 & 8 & 5.0 & 12.0 & 9.5 & 10.2 & $\begin{array}{l}\text { STUART TAU-C } \\
\end{array}$ & -0.107 & 0.045 & -2.353 & \\
\hline 9 & 9 & 7 & 5 & 21 & 9 & 22.5 & 3.5 & 2.5 & 4.8 & SOMERS D & -0.083 & 0.035 & -2.353 & 1 \\
\hline 10 & 5 & 3 & 0 & 8 & 10 & 12.5 & 1.5 & 0.0 & 1.8 & SOMERS D & -0.123 & 0.052 & -2.353 & 10 \\
\hline 11 & 4 & 2 & 0 & 6 & 11 & 10.0 & 1.0 & 0.0 & 1.4 & CORRELATION COEF. & -0.197 & 0.052 & -3.444 & \\
\hline Total & 40 & 200 & 200 & 440 & Total & 100.0 & 100.0 & 100.0 & 100.0 & $\begin{array}{l}\text { SPEARMAN RANK } \\
\text { CORR. }\end{array}$ & -0.120 & 0.050 & -2.396 & \\
\hline
\end{tabular}

LOVE AS A LIFE GOAL

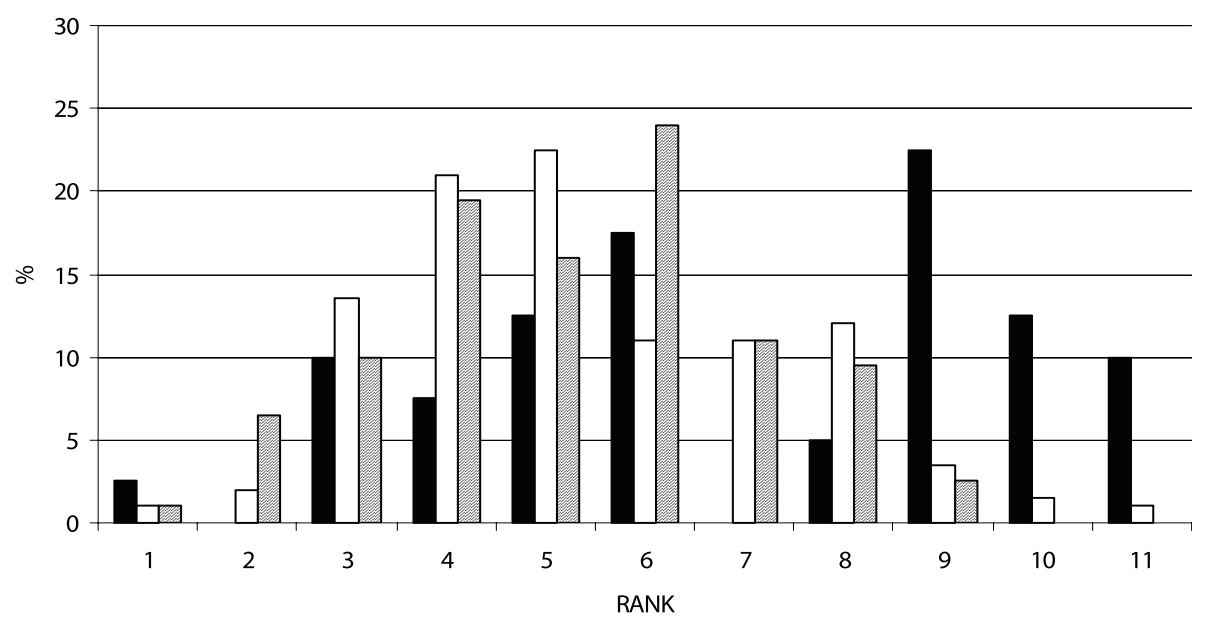

- Private persons $\square$ Managers $\square$ Specialists

Figure 8. Love as a life objective is not interesting for any group of persons questioned 
Table 9. Statistical data for life objective: 9. security

\begin{tabular}{|c|c|c|c|c|c|c|c|c|c|c|c|c|c|c|}
\hline \multicolumn{5}{|c|}{ FREQUENCY TABLE (SAFETY) } & \multicolumn{5}{|c|}{ COLUMN TABLE STRUCTURE (SAFETY) } & \multicolumn{5}{|c|}{ MINIMUM ESTIMATED EXPECTED VALUE IS 0.36} \\
\hline & & Group & & & & & Group & & & STATISTIC & VALUE & D.F. & PROB. & \\
\hline & Private & $\begin{array}{l}\text { Mana- } \\
\text { ger }\end{array}$ & Spec. & Total & & Private & $\begin{array}{l}\text { Mana- } \\
\text { ger }\end{array}$ & Spec. & Total & PEARSON CHISQUARE & 111.495 & 20 & 0.0 & \\
\hline 1 & 0 & 1 & 3 & 4 & 1 & 0.0 & 0.5 & 1.5 & 0.9 & PHI & 0.503 & & & \\
\hline 2 & 1 & 4 & 17 & 22 & 2 & 2.5 & 2.0 & 8.5 & 5.0 & CONTIGENCY COEF. C & 0.450 & & & \\
\hline 3 & 0 & 21 & 12 & 33 & 3 & 0.0 & 10.5 & 6.0 & 7.5 & CRAMER'S V & 0.356 & & & \\
\hline 4 & 2 & 29 & 45 & 76 & 4 & 5.0 & 14.5 & 22.5 & 17.3 & & & & & \\
\hline 5 & 0 & 24 & 30 & 54 & 5 & 0.0 & 12.0 & 15.0 & 12.3 & STATISTIC & VALUE & ASE1 & $\begin{array}{c}\text { T- } \\
\text { VALUE }\end{array}$ & $\begin{array}{l}\mathrm{DE} \\
\mathrm{P} .\end{array}$ \\
\hline 6 & 10 & 46 & 13 & 69 & 6 & 25.0 & 23.0 & 6.5 & 15.7 & GAMMA & -0.278 & 0.054 & -4.997 & \\
\hline 7 & 3 & 28 & 56 & 87 & 7 & 7.5 & 14.0 & 28.0 & 19.8 & KENDALL TAU-B & -0.200 & 0.039 & -4.997 & \\
\hline 8 & 11 & 28 & 18 & 57 & 8 & 27.5 & 14.0 & 9.0 & 13.0 & STUART TAU-C & -0.212 & 0.042 & -4.997 & \\
\hline 9 & 6 & 8 & 6 & 20 & 9 & 15.0 & 4.0 & 3.0 & 4.5 & SOMERS D & -0.164 & 0.032 & -4.997 & 1 \\
\hline 10 & 5 & 6 & 0 & 11 & 10 & 12.5 & 3.0 & 0.0 & 2.5 & SOMERS D & -0.244 & 0.048 & -4.997 & 11 \\
\hline 11 & 2 & 5 & 0 & 7 & 11 & 5.0 & 2.5 & 0.0 & 1.6 & CORRELATION COEF. & -0.282 & 0.044 & -5.603 & \\
\hline Total & 40 & 200 & 200 & 440 & Total & 100.0 & 100.0 & 100.0 & 100.0 & $\begin{array}{l}\text { SPEARMAN RANK } \\
\text { CORR. }\end{array}$ & -0.237 & 0.046 & -5.067 & \\
\hline
\end{tabular}

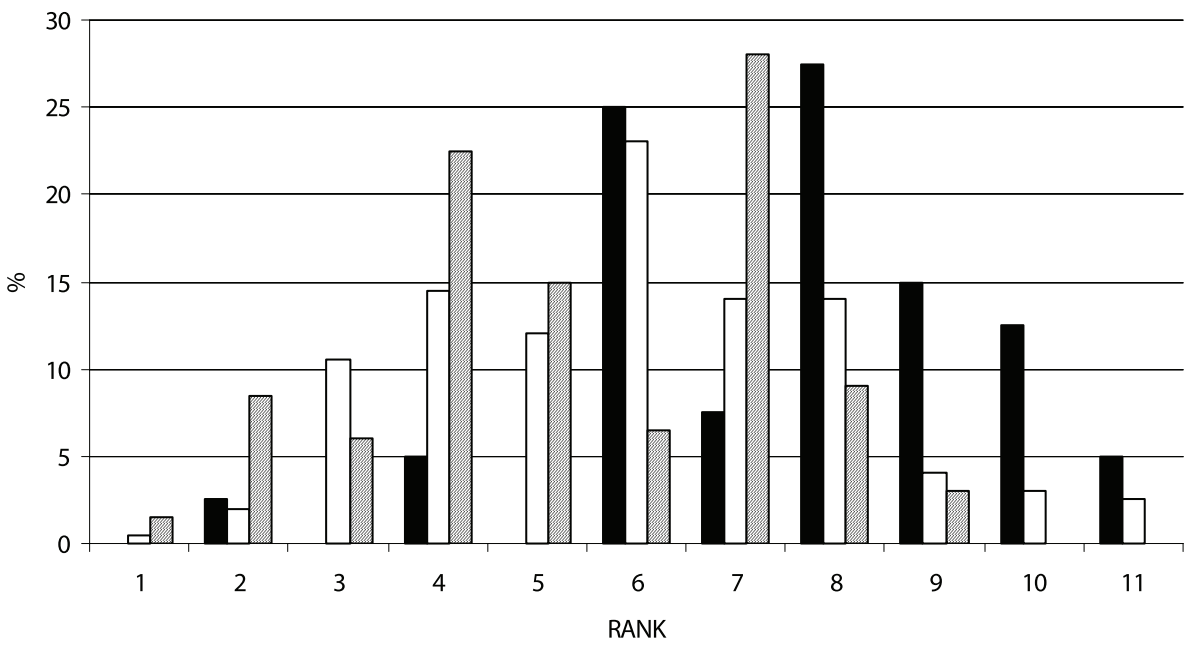

- Private persons $\square$ Managers $\square$ Specialists

Figure 9. Security as a life objective is not interesting for managers and specialists, but it is very important for entrepreneurs

Table 10. Statistical data for life objective: 10. sense of duty

\begin{tabular}{|c|c|c|c|c|c|c|c|c|c|c|c|c|c|c|}
\hline \multicolumn{5}{|c|}{$\begin{array}{c}\text { FREQUENCY TABLE (SENSE OF A } \\
\text { DUTY) }\end{array}$} & \multicolumn{5}{|c|}{ COLUMN TABLE STRUCTURE (DUTY) } & \multicolumn{5}{|c|}{ MINIMUM ESTIMATED EXPECTED VALUE IS $\quad 0.55$} \\
\hline & \multicolumn{3}{|c|}{ Group } & \multirow[b]{2}{*}{ Total } & & \multicolumn{3}{|c|}{ Group } & \multirow[b]{2}{*}{ Total } & \begin{tabular}{|l|} 
STATISTIC \\
\end{tabular} & \begin{tabular}{|l|} 
VALUE \\
\end{tabular} & D.F. & PROB. & \\
\hline & Private & $\begin{array}{c}\text { Mana- } \\
\text { ger }\end{array}$ & Spec. & & & Private & $\begin{array}{c}\text { Mana- } \\
\text { ger }\end{array}$ & Spec. & & PEARSON CHISQUARE & \begin{tabular}{|l|l|}
208.994 \\
\end{tabular} & 20 & 0.0 & \\
\hline 1 & 1 & 25 & 40 & 66 & 1 & 2.5 & 12.5 & 20.0 & 15.0 & PHI & 0.689 & & & \\
\hline 2 & 1 & 43 & 37 & 81 & 2 & 2.5 & 21.5 & 18.5 & 18.4 & \begin{tabular}{|l} 
CONTIGENCY \\
\end{tabular} & 0.567 & & & \\
\hline 3 & 0 & 44 & 40 & 84 & 3 & 0.0 & 22.0 & 20.0 & 19.1 & CRAMER'S V & 0.487 & & & \\
\hline 4 & 6 & 25 & 22 & 53 & 4 & 15.0 & 12.5 & 11.0 & 12.0 & & & & & \\
\hline 5 & 2 & 8 & 3 & 13 & 5 & 5.0 & 4.0 & 1.5 & 3.0 & STATISTIC & VALUE & ASE1 & $\begin{array}{c}\text { T- } \\
\text { VALUE }\end{array}$ & $\begin{array}{l}\mathrm{DE} \\
\mathrm{P} .\end{array}$ \\
\hline 6 & 6 & 20 & 31 & 57 & 6 & 15.0 & 10.0 & 15.5 & 13.0 & $\overline{\text { GAMN }}$ & -0.288 & 0.056 & -4.898 & \\
\hline 7 & 1 & 15 & 22 & 38 & 7 & 2.5 & 7.5 & 11.0 & 8.6 & KENDALL TAU-B & -0.207 & 0.041 & -4.898 & \\
\hline 8 & 0 & 11 & 5 & 16 & 8 & 0.0 & 5.5 & 2.5 & 3.6 & \begin{tabular}{|l|} 
STUART TAU-C \\
\end{tabular} & -0.220 & 0.045 & 4.898 & \\
\hline 9 & 2 & 4 & 0 & 6 & 9 & 5.0 & 2.0 & 0.0 & 1.4 & SOMERS D & -0.169 & 0.034 & -4.898 & 1 \\
\hline 10 & 7 & 3 & 0 & 10 & 10 & 17.5 & 1.5 & 0.0 & 2.3 & \begin{tabular}{|l} 
SOMERS D \\
\end{tabular} & -0.253 & 0.050 & -4.898 & 12 \\
\hline 11 & 14 & 2 & 0 & 16 & 11 & 35.0 & 1.0 & 0.0 & 3.6 & CORRELAT & -0.355 & 0.048 & -5.675 & \\
\hline Total & 40 & 200 & 200 & 440 & Total & 100.0 & 100.0 & 100.0 & 100.0 & $\begin{array}{l}\text { SPEARMAN RANK } \\
\text { CORR. }\end{array}$ & -0.244 & 0.048 & -5.002 & \\
\hline
\end{tabular}


SENSE OF A DUTY AS A UFE GOAL

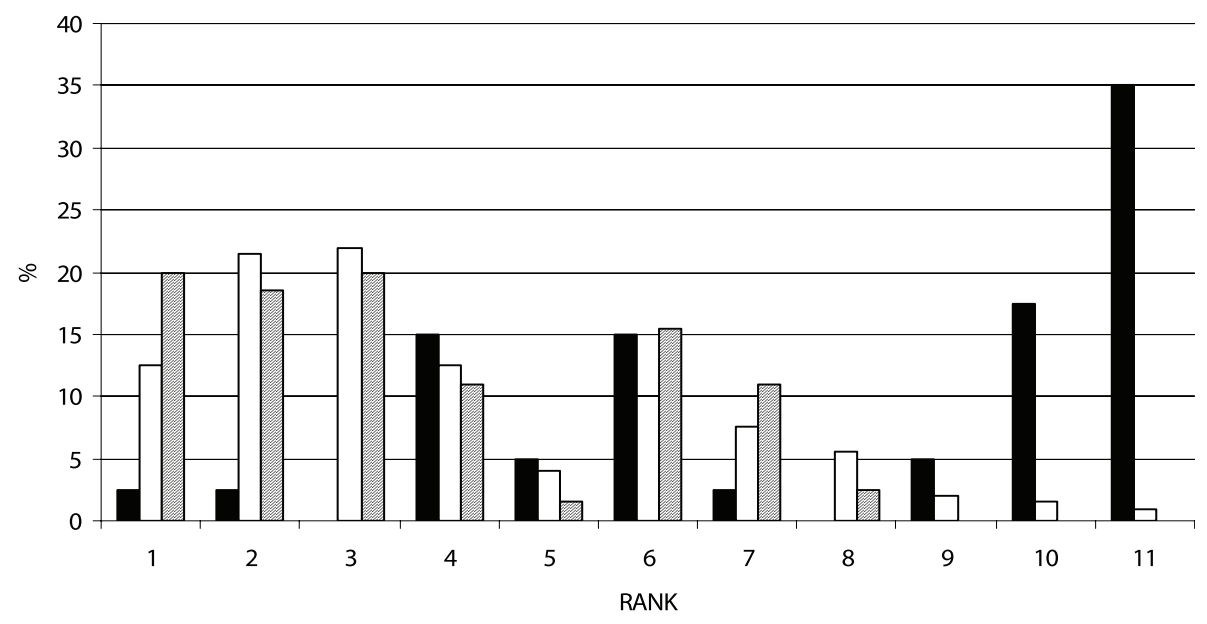

- Private persons $\square$ Managers $\square$ Specialists

Figure 10. Sense of duty as a life objective is a little interesting for successful private owners, but this objective was ranked very high by the group consisted of public enterprise managers and specialists

Table 11. Statistical data for the life objective: 11. pleasure

\begin{tabular}{|c|c|c|c|c|c|c|c|c|c|c|c|c|c|c|}
\hline \multicolumn{5}{|c|}{ FREQUENCY TABLE (SATISFACTION) } & \multicolumn{5}{|c|}{$\begin{array}{l}\text { COLUMN TABLE STRUCTURE } \\
\text { (SATISFAC.) }\end{array}$} & \multicolumn{5}{|c|}{ MINIMUM ESTIMATED EXPECTED VALUE IS $\quad 0.55$} \\
\hline & \multicolumn{3}{|c|}{ Group } & \multirow[b]{2}{*}{ Total } & & \multicolumn{3}{|c|}{ Group } & \multirow[b]{2}{*}{ Total } & STATISTIC & VALUE & D.F. & PROB. & \\
\hline & Private & $\begin{array}{c}\text { Mana- } \\
\text { ger }\end{array}$ & Spec. & & & Private & $\begin{array}{l}\text { Mana- } \\
\text { ger }\end{array}$ & Spec. & & PEARSON CHISQUARE & 78.037 & 20 & 0.0 & \\
\hline 1 & 5 & 2 & 1 & 8 & 1 & 12.5 & 1.0 & 0.5 & 1.8 & PHI & 0.421 & & & \\
\hline 2 & 1 & 2 & 3 & 6 & 2 & 2.5 & 1.0 & 1.5 & 1.4 & CONTIGENCY COEF. C & 0.388 & & & \\
\hline 3 & 6 & 5 & 9 & 20 & 3 & 15.0 & 2.5 & 4.5 & 4.5 & CRAMER'S V & 0.298 & & & \\
\hline 4 & 11 & 38 & 35 & 84 & 4 & 27.5 & 19.0 & 17.5 & 19.1 & & & & & \\
\hline 5 & 2 & 14 & 15 & 31 & 5 & 5.0 & 7.0 & 7.5 & 7.0 & STATISTIC & VALUE & ASE1 & $\begin{array}{c}\text { T- } \\
\text { VALUE }\end{array}$ & $\begin{array}{c}\mathrm{DE} \\
\mathrm{P} .\end{array}$ \\
\hline 6 & 1 & 25 & 33 & 59 & 6 & 2.5 & 12.5 & 16.5 & 13.4 & GAMMA & 0.079 & 0.062 & 1.258 & \\
\hline 72 & 2 & 41 & 30 & 73 & 7 & 5.0 & 20.5 & 15.0 & 16.6 & KENDALL TAU-B & 0.056 & 0.044 & 1.258 & \\
\hline 8 & 4 & 43 & 38 & 85 & 8 & 10.0 & 21.5 & 19.0 & 19.3 & STUART TAU-C & 0.059 & 0.047 & 1.258 & \\
\hline 9 & 2 & 16 & 23 & 41 & 9 & 5.0 & 8.0 & 11.5 & 9.3 & $\begin{array}{l}\text { SOMERS D } \\
\end{array}$ & 0.046 & 0.036 & 1.258 & 1 \\
\hline 10 & 2 & 11 & 13 & 26 & 10 & 5.0 & 5.5 & 6.5 & 5.9 & SOMERS D & 0.068 & 0.054 & 1.258 & 13 \\
\hline 11 & 4 & 3 & 0 & 7 & 11 & 10.0 & 1.5 & 0.0 & 1.6 & CORRELATION COEF. & 0.094 & 0.056 & 1.653 & \\
\hline Total & 40 & 200 & 200 & 440 & Total & 100.0 & 100.0 & 100.0 & 100.0 & $\begin{array}{l}\text { SPEARMAN RANK } \\
\text { CORR. }\end{array}$ & 0.067 & 0.051 & 1.292 & \\
\hline
\end{tabular}

SATISFACTION AS A LIFE GOAL

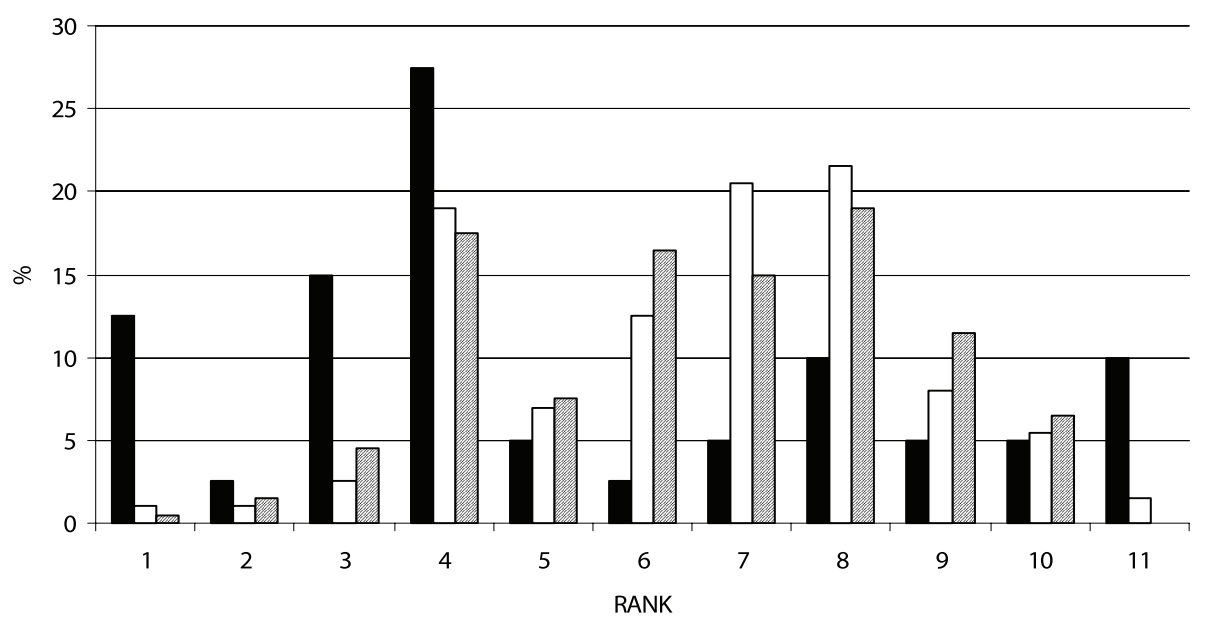

- Private persons $\square$ Managers $\square$ Specialists

Figure 11. Pleasure as a life objective is very important for successful private owners, but it has no significance for public enterprise managers 
In further interpretation of the meaning of research correlants and factors it is necessary to remind about the multiple role of life objective variable.
Table 12 shows statistical significance based on the contingency coefficient $\mathrm{C}$ and $\mathrm{Hi}$ square $\mathrm{H}^{2}$, for all analyzed life objectives.

Table 12. Statistical significance based on the contingency coefficient $C$ and $H i$ square $H^{2}$, for all analyzed life objectives

\begin{tabular}{|l|c|c|}
\hline \multicolumn{1}{|c|}{ Life objectives } & $\begin{array}{c}\text { Contingency coeffi- } \\
\text { cient }\end{array}$ & Hi square \\
\hline 1. Leadership & $\mathrm{C}=0.612$ & $\mathrm{H}^{2}=263.497$ \\
\hline 2. Expertise & $\mathrm{C}=0.474$ & $\mathrm{H}^{2}=127.398$ \\
\hline 3. Creativity & $\mathrm{C}=0.386$ & $\mathrm{H}^{2}=77.117$ \\
\hline 4. Prestige & $\mathrm{C}=0.495$ & $\mathrm{H}^{2}=142.651$ \\
\hline 5. Solidarity & $\mathrm{C}=0.604$ & $\mathrm{H}^{2}=252.633$ \\
\hline 6. Wealth & $\mathrm{C}=0.549$ & $\mathrm{H}^{2}=190.256$ \\
\hline 7. Independence & $\mathrm{C}=0.438$ & $\mathrm{H}^{2}=104.277$ \\
\hline 8. Love & $\mathrm{C}=0.453$ & $\mathrm{H}^{2}=113.859$ \\
\hline 9. Security & $\mathrm{C}=0.450$ & $\mathrm{H}^{2}=111.495$ \\
\hline 10. Sense of duty & $\mathrm{C}=0.567$ & $\mathrm{H}^{2}=208.994$ \\
\hline 11. Pleasure & $\mathrm{C}=0.388$ & $\mathrm{H}^{2}=78.037$ \\
\hline
\end{tabular}

Those data clearly indicate that the difference between statistics is obvious due to high Hi square. Correlation coefficient obtained in research definitely indicates that there is a strong connection between the managers and specialists. It may be concluded that the managers and specialists have identical life objectives, while life objectives of entrepreneurs differ a lot.

This paper confirms the general hypothesis that persons occupying managerial positions in the enterprises and the specialists have different life objective structures in relation to successful private owners - entrepreneurs. It results from the individual psychology, education, cultural environment where they work and develop themselves. Differences in life objectives also happen due the fact that the entrepreneurs are the capital holders and therefore their perception of life and life objectives is completely different.

\section{PRIVATE PERSONS}

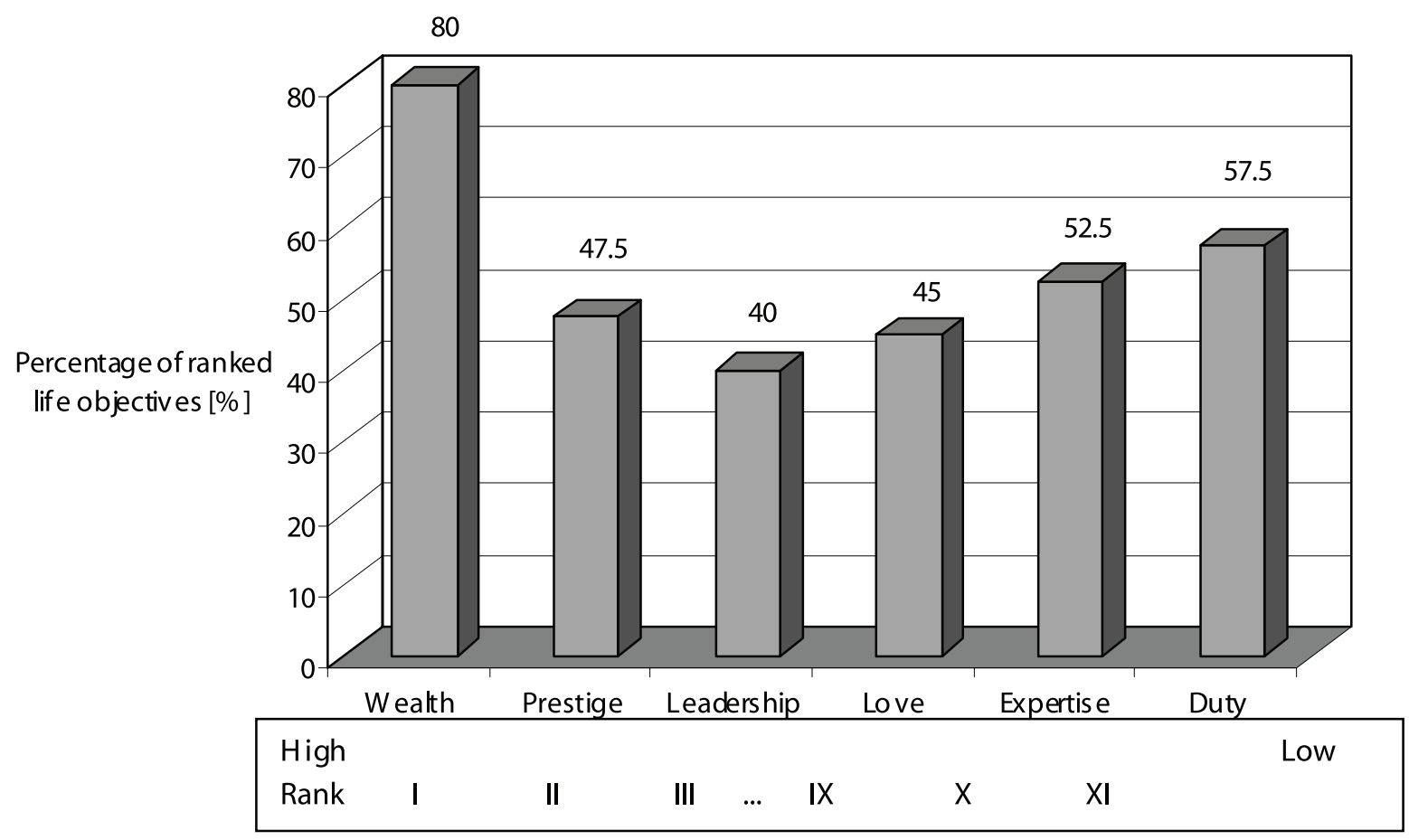

Figure 12. Comparative review of high and low ranked life objectives of entrepreneurs 
MANAGERS

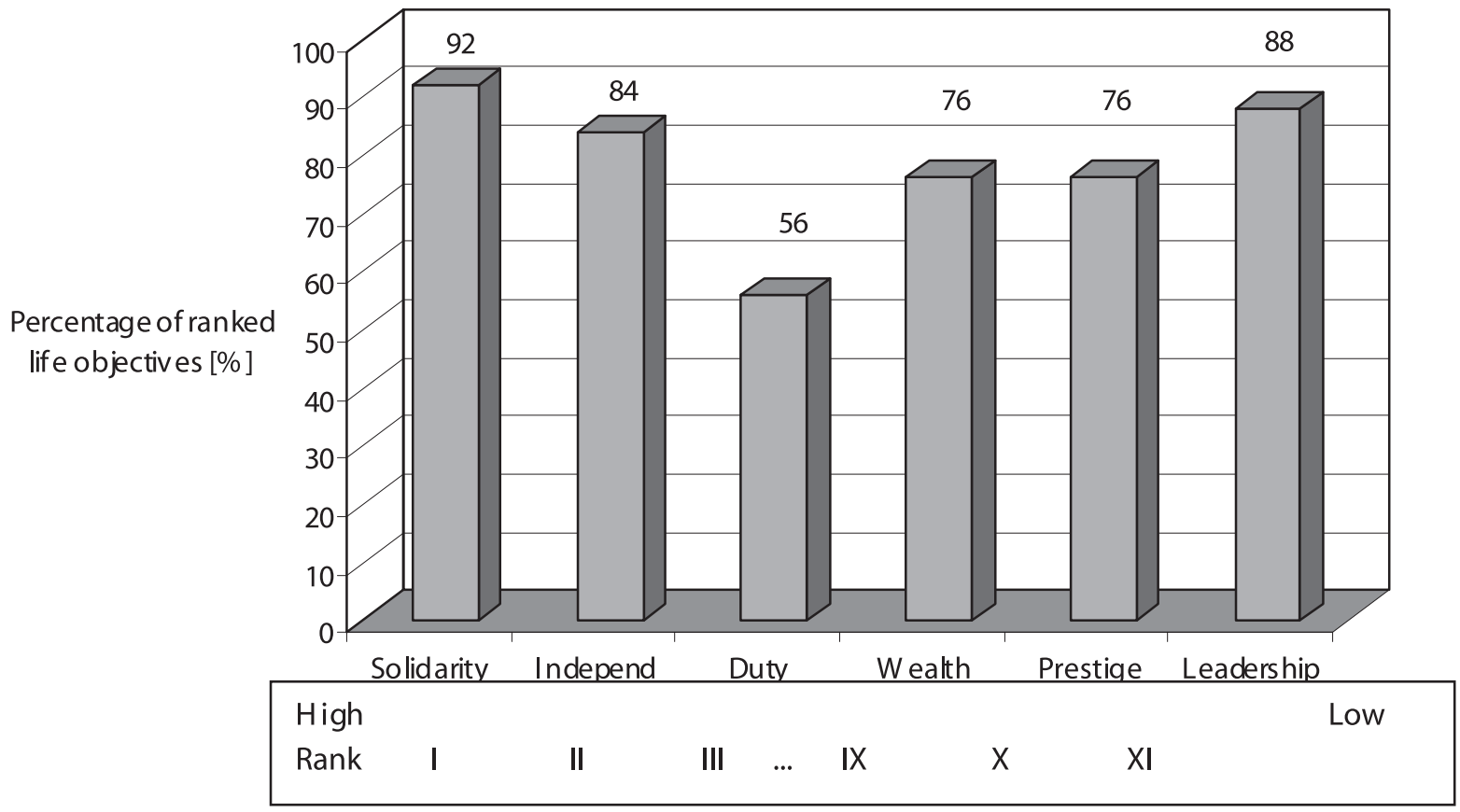

Figure 13. Comparative review of high and low ranked life objectives of managers

\section{SPECIALISTS}

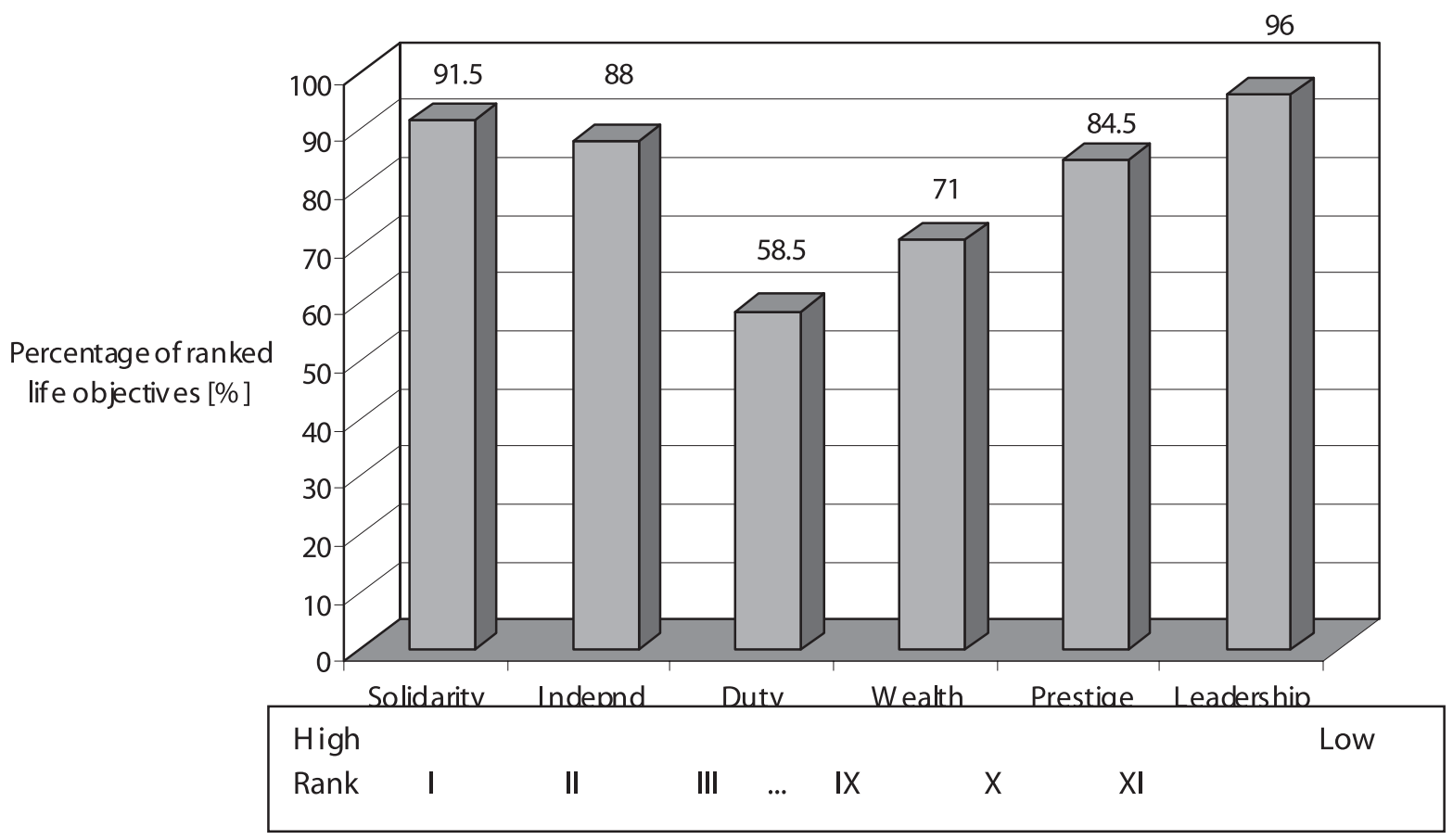

Figure 14. Comparative review of high and low ranked life objectives of specialists 
Comparative review of high and low ranked life objectives is shown in figures 12-14 (figure 12. - entrepreneurs, figure 13. - managers, figure 14. - specialists).

Scientific justifiability of this research is in setting up the difference between the viewpoints and approaches of managers and specialists in their managerial work.

\section{Conclusion}

Correlation coefficient obtained in the research undoubtedly indicates that managers of public enterprises and specialists are tightly connected. Considering the research nature, it can be concluded that managers in public enterprises and specialists have the same life objectives, while life objectives of private owners are completely different. Results of this research can be presented as follows:

- Ranking of life objectives of managers in public enterprises: 1 . solidarity, 2. independence, 3. sense of duty, 4. love, 5. creativity, 6. security, 7. pleasure, 8. expertise, 9. wealth, 10. prestige, 11. leadership.

- Ranking of life objectives of specialists: 1 . solidarity, 2. independence, 3. sense of duty, 4. pleasure, 5. creativity, 6. love, 7. security, 8. expertise, 9. wealth, 10. prestige, 11. leadership.

- Ranking of life objectives of private owners: 1 . wealth, 2. prestige, 3. leadership, 4. pleasure, 5. creativity, 6. security, 7. solidarity, 8. independence, 9. love, 10. expertise, 11 . sense of duty.

The research proved the hypothesis that life objectives of managers in public enterprises and life objectives of private enterprise owners differ a lot. This difference of life objectives results from the fact that managers in public enterprises are not enterprise owners, while self-employed persons are owners of their enterprises. The results of research of these differences fit in the image of managers in private enterprises as more pushing persons in relation to their fellow-workers in public enterprises.

To change the awareness and viewpoints of managers in public enterprises, the following is necessary:

- to make permanent changes in the management area;

- to get knowledge and develop capabilities of managers permanently (in this way, their complete activity would be oriented to the totality of changes);

- to conduct professional orientation of prospective students who commit themselves to managers and management;

- to make selection between prospective students of the Faculty of Management;

- to implement the system for promotion of managers using quantitative methods;

- the management on these bases implies adoption of pedagogical methods in the education process which is appropriate for young people as well as activation of andragogical solutions that will produce better business results by means of managers' life objective structure.
Consistent applying the management practice best ensures making the necessary connections between the knowledge on the research subject and the management practice.

To all appearances, the research results raise expectations that their application will produce multiple economic and social benefits. Economic benefit - in the sense that appropriate application of research results will increase management efficiency and better business results will be achieved. Social benefit - in the sense that research results will enable more efficient development of enterprise management. The condition to achieve abovementioned benefits is that other factors, including supply level of production materials, working discipline, good work organization, etc. operate in mutually dependent interaction.

\section{Literature}

Braham, J. (1989). Human Resource Planning, IPM, London. Butteress, M. \& Albrecht, K. (1979). New Management Tools, Englewood, Prentice-Hall, New York.

Coleman, D. (1997). Groupware: Collaborative Strategies for Corporate LaNs and Intranets, Engelwod Cliffs, Prentice Hall, New York.

Donnelly, Jr. J., Gibson L. J. \& Ivancevich, M., J. (1990). Fundamentals of Management, 7th Edition, BPI - IRWIN, Homewood, Boston.

Harris, M. (1997). Human Resource Management - A Practical Approach, The Dryden Press, Forth Worth, TX.

Ichio, K. \& Nonaka, I. (2007). Knowledge Creation and Management, New Challenges for Managers, Oxford University Press.

Kolb, D. A. (1984). Experimental Learning, Experience as the Source of Learning and Development, Engelwood Cliffts, Prentice Hall, New York.

Likert, R. (1967). The Human Organization - ITS Management and Value, Mcgraw-Hil Bok Company, New York.

Locke, E. A. \& Bryan, J. F. (1967). Performance Goals As Determinants of Level of Performance Boredom, Journal of Applied Psychology, 51 (March), pp. 120-130.

Lunday, O. \& Cowling, A. (1996). Strategic Human Resource Management, Routledge, London.

McGregor, D. (1957). An Uneasy Look at Performance Appraisal, Harvard Business Review, 35(3): 89 - 94.

Meggison, L.C., Franklin, G.M. \& Byird, M.J. (1995). Human Resource Management, DAME, Houston, TX.

Peters, T. (1987). Thriving on chaos: Handbook for a management revolution, New York, Harper \& Row

Rothenback, F. W. (1982). Career Development: Ask Your Employees for Their Opinions, Personnel Administrator, 27 (November), pp. 43-51.

Sajfert, Z., Djordjevic, D. \& Atanaskovic, P. (2007). Different Structure of Life Objectives of Managers and Enterpreneurs in Serbia, 9th International Scientific Conference, Management Horizons Visions and Challenges, Kaunas, Lithuania, 27-28. September.

Snoveden, D. (1999). Liberating Knowledge, Caspian Publishing, London.

Ulrich, D. and Yeung, A. (1989) A shared mindset, Personnel Administrator, 34 (March), pp. 38-45. 
Von Krogh, G., Ichio, K. \& Nonaka, I. (2000) Enabling Knowledge Creation: How to Unlock the Mystery of Tacit Knowledge and Release the Power of Information, New York, Oxford University Press.

Weihrich, H. \& Koontz H. (1993) Management: A Global Perspective, Mc Graw-Hill, Inc., New York.

Weihrich, H. (1976). The Application of Management by Objectives in Government, Faculty Working Paper MG, Arizona State University.

Wiig, K. (2004). People-Focus Knowledge Management - How Effective Decision Making Leads to Corporate Success, Jorda Hull, Oxford, USA.

Zvonko Sajfert graduated from the Faculty of Organizational Sciences, University of Belgrade in 1989. From the same faculty, he received his Master's degree in 1992 and his Doctor's degree in 1994. Zvonko Sajfert is currently working at the Technical Faculty "Mihajlo Pupin" in Zrenjanin (University of Novi Sad). He was elected to the position of a full professor at University of Novi Sad. Narrower field of his research interest is Human Resource Management. He has published about 100 scientific papers.

Milan Nikolić graduated from the Technical Faculty "Mihajlo Pupin" in Zrenjanin (University of Novi Sad), and received his Master's degree from the same faculty in 2001. He defended his PhD thesis at the Faculty of Mechanical Engineering, University of Belgrade, in 2004. In 2005 Milan Nikolić became an assistant professor (docent) at the Technical Faculty "Mihajlo Pupin" in Zrenjanin. The basic fields of his research interest are Decision Theory and Quantitative Methods in Management. He has published about 70 papers.

Dejan Djordjević graduated from the Faculty of Economics, University of Belgrade in 1990. He received his Master's degree at the same faculty in 1994, and his Doctor's degree 1999. In 2005 Dejan Đorđević became an associate professor at the Technical Faculty "Mihajlo Pupin" in Zrenjanin. The basic fields of his research interest are Marketing and Quality Management. He has published about 90 papers.

Predrag Atanasković graduated from the Faculty of Traffic and Transport Engineering, University of Belgrade in 1985. He received his Master's degree from the same faculty in 1999, and defended his PhD thesis in 2007 at the Technical Faculty "Mihajlo Pupin" in Zrenjanin. In 2008 Predrag Atanasković became a assistant professor (docent) at the Faculty of Technical Sciences, Novi Sad. The basic fields of his research interest are Investment and Project Management. He has published about 40 papers. 